\title{
The Ethiopia Afar Geoscientific Lithospheric Experiment (EAGLE): Probing the transition from continental rifting to incipient seafloor spreading
}

\author{
Ian D. Bastow* \\ Department of Earth Sciences, University of Bristol, Bristol, BS8 1RJ, UK \\ Derek Keir ${ }^{\dagger}$ \\ School of Earth and the Environment, University of Leeds, Leeds, LS2 9JT, UK \\ Eve Daly \\ Department of Earth and Ocean Sciences, National University of Ireland, Galway, Ireland
}

\begin{abstract}
The Miocene-Holocene East African Rift in Ethiopia is unique worldwide because it subaerially exposes the transition between continental rifting and seafloor spreading within a young continental flood basalt province. As such, it is an ideal study locale for continental breakup processes and hotspot tectonism. Here, we review the results of a recent multidisciplinary, multi-institutional effort to understand geological processes in the region: The Ethiopia Afar Geoscientific Lithospheric Experiment (EAGLE). In 2001-2003, dense broadband seismological networks probed the structure of the upper mantle, while controlled-source wide-angle profiles illuminated both along-axis and across-rift crustal structure of the Main Ethiopian Rift. These seismic experiments, complemented by gravity and magnetotelluric surveys, provide important constraints on variations in rift structure, deformation mechanisms, and melt distribution prior to breakup. Quaternary magmatic zones at the surface within the rift are underlain by high-velocity, dense gabbroic intrusions that accommodate extension without marked crustal thinning. A magnetotelluric study illuminated partial melt in the Ethiopian crust, consistent with an overarching hypothesis of magmaassisted rifting. Mantle tomographic images reveal an $\sim 500-\mathrm{km}$-wide low-velocity zone at $\geq 75 \mathrm{~km}$ depth in the upper mantle that extends from close to the eastern edge of the Main Ethiopian Rift westward beneath the uplifted and flood basaltcapped NW Ethiopian Plateau. The low-velocity zone does not interact simply with the Miocene-Holocene (rifting-related) base of lithosphere topography, but it also provides an abundant source of partially molten material that assists extension of the seismically and volcanically active Main Ethiopian Rift to the present day.
\end{abstract}

\footnotetext{
*ian.bastow@bristol.ac.uk

Current address: National Oceanography Centre, University of Southampton, Southampton, SO14 3ZH, UK.
}

Bastow, I.D., Keir, D., and Daly, E., 2011, The Ethiopia Afar Geoscientific Lithospheric Experiment (EAGLE): Probing the transition from continental rifting to incipient seafloor spreading, in Beccaluva, L., Bianchini, G., and Wilson, M., eds., Volcanism and Evolution of the African Lithosphere: Geological Society of America Special Paper 478, p. 1-26, doi:10.1130/2011.2478(04). For permission to copy, contact editing @ geosociety.org. (C) 2011 The Geological Society of America. All rights reserved. 


\section{INTRODUCTION}

\section{Overview}

Continental rifts mark zones of lithospheric thinning and heating in response to extension, and these zones of plate stretching may eventually become the site of continental rupture. Lithospheric thinning may induce adiabatic upwelling and melting of the asthenosphere, leading to magmatism during rifting. Magmatism is enhanced further in regions of anomalously hot mantle, such as the East African Rift (e.g., White and McKenzie, 1989; Ebinger, 2005). Fault-bounded rift systems are long, relatively narrow systems in cratonic lithosphere and wide zones of basins and ranges in collapsing orogenic belts (e.g., Buck, 1991; Hopper and Buck, 1993). The geological record shows that if tensional stresses are sufficient and sustained enough to thin and rupture the rigid 150-250-km-thick continental lithospheric plates, extension can lead to complete continental breakup and the subsequent creation of new oceanic lithosphere (e.g., Buck, 2004; Ebinger, 2005). After rupture, the now-inactive rift zone becomes a "passive margin" that subsides beneath sea level as the heat transferred from the asthenosphere to the plate during rifting finally dissipates (e.g., McKenzie, 1978; Bown and White, 1995).

Many passive margins worldwide are "magmatic margins," characterized by thick sequences of extruded, intruded, and underplated igneous rocks emplaced prior to, or during, rifting (e.g., Coffin and Eldholm, 1994; Menzies et al., 2002). Extension is accommodated through the combined processes of faulting, ductile stretching, and magma intrusion in the form of dikes and sills (e.g., Ebinger and Casey, 2001; Buck, 2004, 2006). Pressure gradients caused by topographic relief on the lithosphereasthenosphere boundary beneath continents may guide the distribution of melt hundreds of kilometers from the zone of mantle melting (e.g., Sleep, 1996; Ebinger and Sleep, 1998) and, as such, influence the localization of intrusive and extrusive magmatism. Despite the global abundance of ancient magmatic margins, the timing and distribution of magmatism, as well as the strain partitioning among faulting, ductile stretching, and magma intrusion are not well understood because the ocean-continent boundary is concealed by thick seaward-dipping reflectors (e.g., Mutter et al., 1982; Mutter, 1985; Holbrook and Kelemen, 1993). Additionally, many passive margins worldwide ruptured during Gondwana breakup prior to ca. $100 \mathrm{Ma}$, so the exact nature of the continentocean transition has to be deduced rather than directly observed.

Continental rift zones worldwide are structurally segmented along their length, but the length scales and character of the along-axis segmentation may change during rift evolution (e.g., Hayward and Ebinger, 1996; d'Acremont et al., 2005). During the initial rift stages, basin dimension scales with the mechanical thickness of the lithosphere, with long, wide basins forming in strong lithosphere (e.g., Buck, 1991; Ebinger et al., 1999). As lithospheric thinning and heating continue, strain localizes to a narrower zone in response to reduced lithospheric strength. In addition, an increase in magma intrusion may play an important role in localizing strain as well as weakening the lithosphere by heating (Ebinger and Hayward, 1996; Pérez-Gussinyé et al., 2009), thereby significantly influencing along-axis segmentation of the rift (e.g., Ebinger and Casey, 2001; Wolfenden et al., 2004). If rifting continues to the point of continental rupture, then full oceanic spreading is established and results in the formation of new lithosphere (e.g., Kuo and Forsyth, 1988; Phipps-Morgan and Chen, 1993; Wang et al., 2009).

EAGLE (Ethiopia Afar Geoscientific Lithospheric Experiment) probed the crust and upper mantle in the seismically and volcanically active East African Rift system in Ethiopia using passive and controlled-source seismology as well as complementary geophysical techniques such as gravity and magnetotelluric surveying (e.g., Maguire et al., 2003). This synthesis of geophysical and geological results from EAGLE aims to summarize new constraints on (1) the generation and migration of melt beneath the rift, and (2) the relative importance of faulting, magma intrusion, and ductile stretching in accommodating extension during the final stages of continental breakup. The results further our understanding of both hotspot tectonism and evolution of lithospheric structure during incipient oceanic spreading and continental margin formation. We also summarize the many tectonic questions raised by the project—questions that will fuel future generations of research in East Africa.

\section{Tectonic Setting}

The term "rift valley" was first introduced by Gregory (1896) to describe the fissure in Earth's surface into which a strip of the surface has been let down by parallel faults. When Gregory penned his famous work at the end of the nineteenth century, he also remarked that the scar in the East African landscape before him was likely an extensional feature. We now know that the Ethiopian Rift forms the third arm of the East African-Red Sea-Gulf of Aden rift-rift-rift triple junction where the Arabian, Nubian, Somalian, and Danakil plates join in Afar (Fig. 1) (McKenzie and Morgan, 1969; McKenzie and Davies, 1970). Embryonic magmatic rifting of the continental lithosphere is observed to the south in northern Tanzania and southern Kenya (Maguire et al., 1994; Nyblade et al., 1996). To the northeast of the East African Rift in Ethiopia, incipient seafloor spreading is evident in the Asal Rift, which is the onshore westward extension of the Gulf of Aden spreading ridge (e.g., Ruegg and Kasser, 1987; Stein et al., 1991; De Chabalier and Avouac, 1994). The Red Sea Rift arm encompasses incipient seafloor spreading in northern Afar, including the currently active Dabbahu and Erta Ale Rift segments. The Ethiopian Rift is the least evolved, youngest of the three rift arms and terminates at the Tendaho Goba'ad discontinuity in central Afar (e.g., Tesfaye et al., 2003; Wolfenden et al., 2005; Bellahsen et al., 2003) (Fig. 1).

The Miocene-Holocene East African Rift in Ethiopia subaerially exposes the transitional stage of rifting within a young continental flood basalt province, making it an ideal study location for continental breakup processes. In addition to 


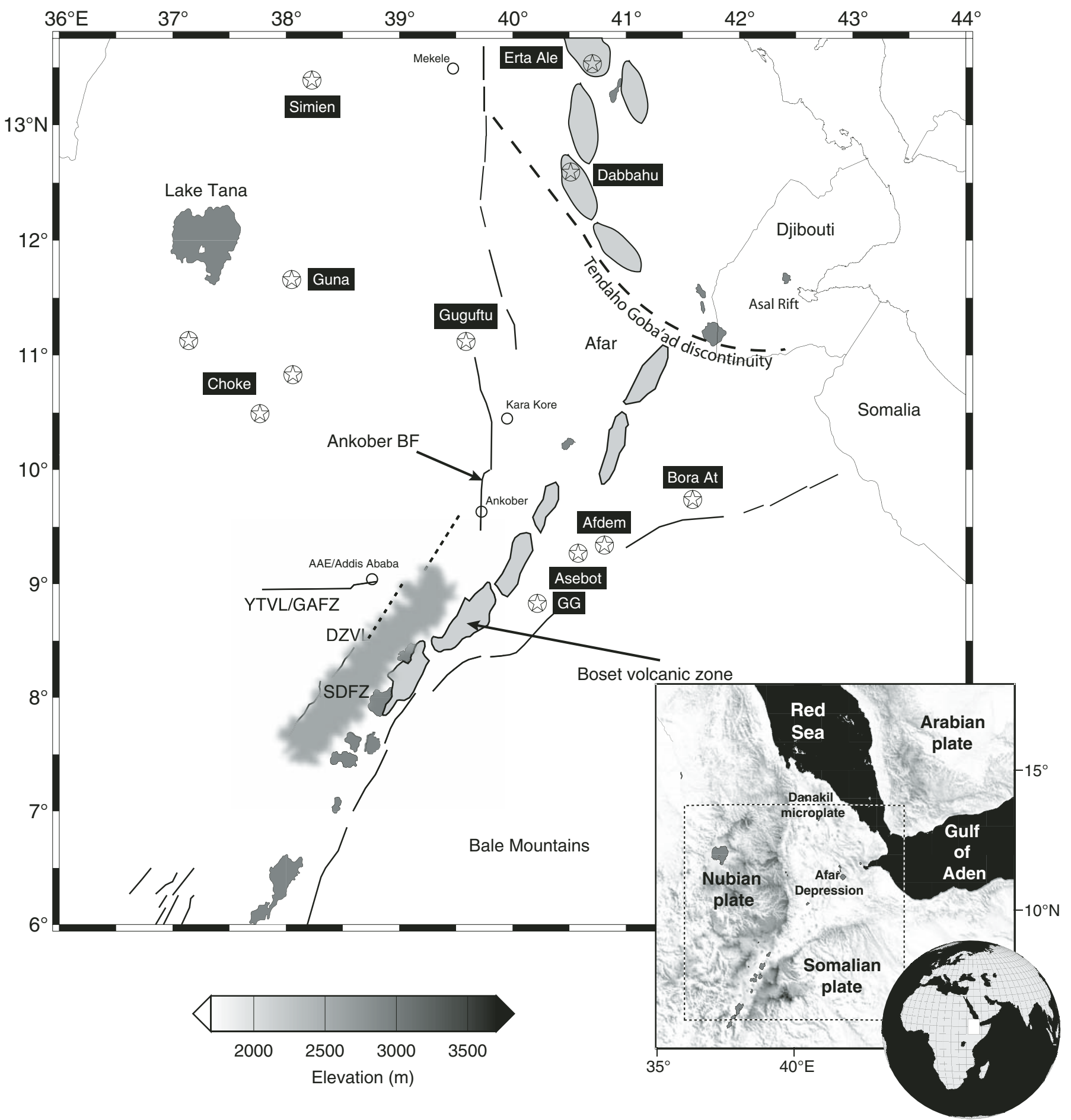

Figure 1. Location map of Ethiopia. Major mid-Miocene border faults are solid black lines, and Quaternary magmatic zones that delineate the Wonji fault belt are shaded gray and delineated by the heavy black lines; dashed lines are faulted monoclines. Stars are selected PlioceneMiocene volcanoes. SDZF—Silti Debre Zeyit fault zone; GAFZ—Guder Ambo fault zone; YTVL_Yerer-Tullu Wellel volcanotectonic lineament. Open circles show locations of towns/cities. Inset: Regional tectonic setting on a topographic map. BF-Border Fault; GG-Gara Gumbi; DZVL—Debre Zeit Volcanic Lineament. 
transitional rifting processes, Ethiopia is also an ideal natural laboratory for the study of hotspot tectonism. Seismic imaging reveals a broad ( $\sim 500$-km-wide) $\sim 3 \%$ S-wave low-velocity anomaly that originates at the core-mantle boundary beneath southern Africa and rises toward the base of the lithosphere somewhere in the region of Ethiopia and the Red Sea-Gulf of Aden (Grand, 2002; Ritsema and Allen, 2003; Simmons et al., 2007; Li et al., 2008): the African superplume. When reviewed in light of other geophysical observations that can be used to constrain mantle convection (e.g., the global freeair gravity field, tectonic plate motions, and dynamic surface topography), the morphology and sharp velocity gradients of the African superplume are explained best by a thermochemical plume rising from the core-mantle boundary (e.g., Ni et al., 2002; Simmons et al., 2007). There is increasing evidence from global tomographic studies that low-velocity structures could be continuous across the 410 and $660 \mathrm{~km}$ discontinuities in the Kenya-Ethiopia region (e.g., Ritsema and Allen, 2003; Li et al., 2008; Montelli et al., 2004, 2006, and references therein; Sicilia et al., 2008), but the precise location and number of upwellings beneath East Africa remain somewhat controversial.

The timing of the widespread and voluminous volcanism in the Ethiopia-Yemen area suggests that this mantle upwelling impinged on the base of the lithosphere ca. $45 \mathrm{Ma}$, prior to the onset of rifting of Arabia from Africa at ca. $30 \mathrm{Ma}$ (e.g., Wolfenden et al., 2004). The earliest Cenozoic volcanism in East Africa occurred in southwest Ethiopia and the Turkana Depression in northernmost Kenya at 40-45 Ma (e.g., Ebinger et al., 1993; George et al., 1998; Furman et al., 2006). This area had been rifted during the Mesozoic breakup of Gondwana (e.g., Hendrie et al., 1994). Approximately $2 \mathrm{~km}$ of basalts and subordinate rhyolites were then erupted rapidly across the Ethiopian Plateau at ca. 29-31 Ma (Baker et al., 1996; Hofmann et al., 1997) prior to or concomitant with the onset of rifting in the Red Sea and Gulf of Aden (e.g., Wolfenden et al., 2004). Additional isolated shield volcanism in the interval ca. 30-10 Ma occurred across the Ethiopian Plateau (Fig. 1) and added $\sim 2 \mathrm{~km}$ of additional local relief in areas such as the Simien, Choke, and Guguftu shield volcanoes (e.g., Kieffer et al., 2004; Beccaluva et al., 2009). However, the timing of uplift in Ethiopia is controversial; commencement has been estimated at 20-30 Ma on the basis of U-Th/He thermochronometry data (Pik et al., 2003), but more recent studies indicate an episodic uplift history with $\sim 1 \mathrm{~km}$ uplift being produced more recently (ca. $10 \mathrm{Ma}$-present); this is postulated to be due to foundering of the plateau lithosphere by delamination or convective removal of lithospheric mantle (e.g., Duggen et al., 2003; Molnar et al., 1993) following extensive heating and weakening since the onset of flood basalt volcanism at ca. $30 \mathrm{Ma}$ (Gani et al., 2007).

Although prerift basement is rarely exposed beneath the thick Eocene-Holocene volcanic cover, the Main Ethiopian Rift is thought to have formed within the Precambrian metamorphic crustal basement of the Pan-African Mozambique belt (Kazmin et al., 1978), which exhibits N-S to NNE-SSW suture zones
(Vail, 1983; Berhe, 1990) and NW-SE-oriented strike-slip faults (Brown, 1970; Purcell, 1976). Extension in SW Ethiopia and the Turkana Depression in northern Kenya commenced by ca. $20 \mathrm{Ma}$, with the central and northern sectors of the Main Ethiopian Rift developing between 18 and $10 \mathrm{Ma}$, respectively (e.g., WoldeGabriel, 1988; Wolfenden et al., 2004). Large offset border faults formed along one or both sides of the rift (Fig. 1) and are often marked by chains of silicic centers (e.g., Chernet et al., 1998). South of $\sim 7.5^{\circ} \mathrm{N}$, a broad ( 500-km-wide) faulted region extends to the west of the present-day Main Ethiopian Rift and marks the zone across which the axis of the Main Ethiopian Rift has migrated east since Oligocene times (e.g., Ebinger et al., 2000).

The distribution, kinematics, and estimated age of fault populations suggest that deformation in the Main Ethiopian Rift north of $8.5^{\circ} \mathrm{N}$ migrated to the center of the rift sometime in the interval 6.6-3 Ma, with an associated change from $\mathrm{N} 130^{\circ} \mathrm{E}$ directed extension to $\mathrm{N} 105^{\circ} \mathrm{E}$-directed extension (Bonini et al., 1997; Boccaletti et al., 1998; Wolfenden et al., 2004). Opening models of the East African Rift based on global positioning system (GPS) data and earthquake focal mechanisms constrain the current extension direction in the Main Ethiopian Rift to between $\mathrm{N} 95^{\circ} \mathrm{E}$ and $\mathrm{N} 110^{\circ} \mathrm{E}$ at rates of $4-7 \mathrm{~mm} / \mathrm{yr}$ (Bilham et al., 1999; Fernandes et al., 2004; Calais et al., 2006; Stamps et al., 2008). GPS data collected during 1969-1997 from the Main Ethiopian Rift and adjacent plateaus indicate that $\sim 80 \%$ of this present-day strain is localized within an $\sim 30-\mathrm{km}$-wide zone within the rift valley (Bilham et al., 1999). On the strength of this evidence, Casey et al. (2006) proposed that the locus of extension in this transitional rifting environment has localized progressively since ca. $12 \mathrm{Ma}$, away from the mid-Miocene border faults, toward central en-echelon chains of eruptive magmatic centers, dikes, and small offset faults. Thus, axial magmatic emplacement, not border faulting, increasingly dominates the rifting process after the initial stages of breakup (e.g., Ebinger and Casey, 2001; Keranen et al., 2004; Rooney et al., 2005; Kurz et al., 2007; Keranen and Klemperer, 2008). Numerical modeling suggests that once an elongate zone of diking is established in the rift axis, the strong, cooled mafic intrusions function to focus extensional stress and thereby promote emplacement of new dikes into the narrow zone of intrusion (Beutel et al., 2010).

Geochemistry provides constraints on the evolving lithosphere, as well as the development of faulting and lithospheric thinning (e.g., Peccerillo et al., 2003; Ronga et al., 2010). Much of the Quaternary magmatic activity within the Main Ethiopian Rift has occurred in magmatic zones in the center of the rift north of $8.5^{\circ} \mathrm{N}$ in the Wonji fault belt (e.g., Mohr, 1967; Ebinger and Casey, 2001; Abebe et al., 2007), where magmas fractionate at shallow $\left(<5 \mathrm{~km}\right.$ ) depths (Rooney et al., 2007). South of $8.5^{\circ} \mathrm{N}$, the Wonji fault belt appears offset within the Main Ethiopian Rift toward the Somalian plate and is flanked to the west by the Silti Debre Zeyit fault zone (SDFZ, Fig. 1), in which magmas fractionate at various depths throughout the crust (Rooney et al., 2005, 2007; Rooney, 2010). These differences in magmatic 
plumbing system north and south of $\sim 8.5^{\circ} \mathrm{N}$ (Rooney et al., 2007), combined with structural and geochronological evidence that the $\sim 7.5^{\circ}-9.5^{\circ} \mathrm{N}$ sector of the rift is the youngest (Bonini et al., 2005), suggest that a simple south-to-north transition from continental rifting to seafloor spreading may be inappropriate. Buck (2006) noted the straightness of the East African and Red Sea Rifts and suggested that this straightness is in part controlled by movement of melt-filled dikes through the plates. It is intriguing, therefore, to note that the Wonji fault belt is remarkably straight throughout the Main Ethiopian Rift. Its apparent offset toward the SE Ethiopian Plateau south of $8.5^{\circ} \mathrm{N}$ is due in part to the kink in the mid-Miocene border faults at this latitude.

The ongoing extension in the Main Ethiopian Rift continues to alter rift morphology and cause natural phenomena such as earthquakes, surface fissuring, and volcanic eruptions. Prior to the temporary deployments of dense seismic networks in Ethiopia since the turn of the millennium, assessment of seismotectonics and seismic hazard was based primarily on relatively few earthquakes ( $M>\sim 3.5$ ) recorded since ca. 1960 by sparse permanent stations in Ethiopia and surrounding countries, as well as from Global Seismograph Network/Global Dense Seismograph Network permanent stations (e.g., Gouin, 1979; Kebede and Kulhánek, 1994; Kebede and van Eck, 1997; Ayele and Kulhánek, 1997; Foster and Jackson, 1998; Ayele, 2000). These data show that seismic moment release over the last $\sim 50 \mathrm{yr}$ in the Main Ethiopian Rift accounts for less than $50 \%$ of total geodetic moment predicted from the current rate of plate opening. This lends some support to the importance of aseismic processes (e.g., diking) in accommodating strain (Hofstetter and Beyth, 2003). Localized, rift-axial brittle failure in the Main Ethiopian Rift is manifest in development of extensional fissures at the surface and associated fault growth in the upper crust (e.g., Asfaw, 1982; Acocella and Korme, 2002; Acocella et al., 2003; Williams et al., 2004; Soliva and Schultz, 2008; Kidane et al., 2009). In addition to brittle strain, magma intrusion and extrusion processes in the Main Ethiopian Rift are known to have occurred episodically since historical times to the present day (e.g., Gibson, 1969; Tadesse et al., 2003; Williams et al., 2004). Asfaw et al. (1992) postulated that deformation in the Main Ethiopian Rift occurs primarily during episodic, magma-dominated rifting episodes similar to those observed in Iceland and the subaerial Red Sea and Aden Rifts in Afar (e.g., Abdallah et al., 1979; Björnsson et al., 1977; Wright et al., 2006; Ayele et al., 2007a; Rowland et al., 2007; Hamling et al., 2009; Keir et al., 2009a; Ebinger et al., 2010).

\section{EAGLE-THE EXPERIMENTS AND MAIN OBSERVATIONS}

In this section, we review the major components of EAGLE from controlled-source profiles that probe crustal-scale structures to three-dimensional (3-D) imaging of the deeper mantle structures using passive-source seismological techniques. The passive-source seismic and geodetic experiments also constrain kinematics and dynamics of the current stage of rifting, and along-axis variations provide clues as to temporal development. We summarize the major observations from these studies before discussing their significance in the context of continental rifting and hotspot tectonism.

\section{Passive Seismic Networks}

Based on the requirement for seismic body-wave tomography of crossing rays in the mantle to a depth of $\sim 300 \mathrm{~km}$ beneath Ethiopia, the 29 station EAGLE phase I broadband network of 20 Güralp CMG-40TD instruments and 9 CMG3TD instruments (e.g., Bastow et al., 2005) was designed with a nominal spacing of $40 \mathrm{~km}$ covering a region of the rift and its uplifted flanks measuring $250 \times 350 \mathrm{~km}$ (Fig. 2). The network was centered on the Boset volcanic zone in the center of the rift, $\sim 75 \mathrm{~km} \mathrm{SE}$ of Addis Ababa. Seismometers recorded at 50 s.p.s. (samples per second) for 16 mo between October 2001 and February 2003. EAGLE phase I was deployed in the footprint of the broader Pennsylvania State University Ethiopia Broadband Seismic Experiment (EBSE; Fig. 2) (Nyblade and Langston, 2002; Brazier et al., 2008).

Between October 2002 and February 2003, 50 Güralp CMG-6TD instruments recording at 100 s.p.s. (Fig. 2) operated mainly in the Main Ethiopian Rift as EAGLE phase II (e.g., Keir et al., 2006b). The $\sim 10 \mathrm{~km}$ station spacing covered regions of active seismicity and was specifically designed to: (1) improve the accuracy of hypocenter locations; (2) increase ray coverage in a joint inversion of local earthquake arrival times for locations and seismic velocity structure; and (3) provide information from which we could infer the position and depth of active faults and therefore illuminate how the locus of seismic deformation in the upper crust compares with variations in crustal structure caused by intrusion of magma. (4) The study is also valuable for future assessment of seismic hazard since it provides the first highresolution snapshot of seismicity in the Ethiopian Rift.

The final broadband component of the EAGLE project (EAGLE phase III) recorded data between November 2002 and January 2003 (Fig. 2), during which 91 Güralp CMG-6TD broadband seismometers were deployed at $5 \mathrm{~km}$ intervals along the cross-rift controlled-source profile recording at 100 s.p.s. with the aim of better understanding cross-rift variations in crustal structure (Cornwell et al., 2010).

\section{Mantle Seismic Tomography}

Mantle seismic tomography is a useful tool for mapping the structure of seismic velocity anomalies and hence the morphology of upwellings and magma source zones beneath rifts (e.g., Evans and Achauer, 1993; Wang et al., 2009). Bastow et al. (2005, 2008) performed regularized nonlinear, least-squares inversion of P- and S-wave traveltime residuals for broadband stations in Ethiopia. These studies built on images from global tomographic studies (Ritsema and van Heijst, 2000; Grand, 2002; Li et al., 2008) and regional studies in the area (Debayle et al., 2001; Benoit et al., 2006a, 2006b; Pasyanos and Nyblade, 2007; Priestley et 


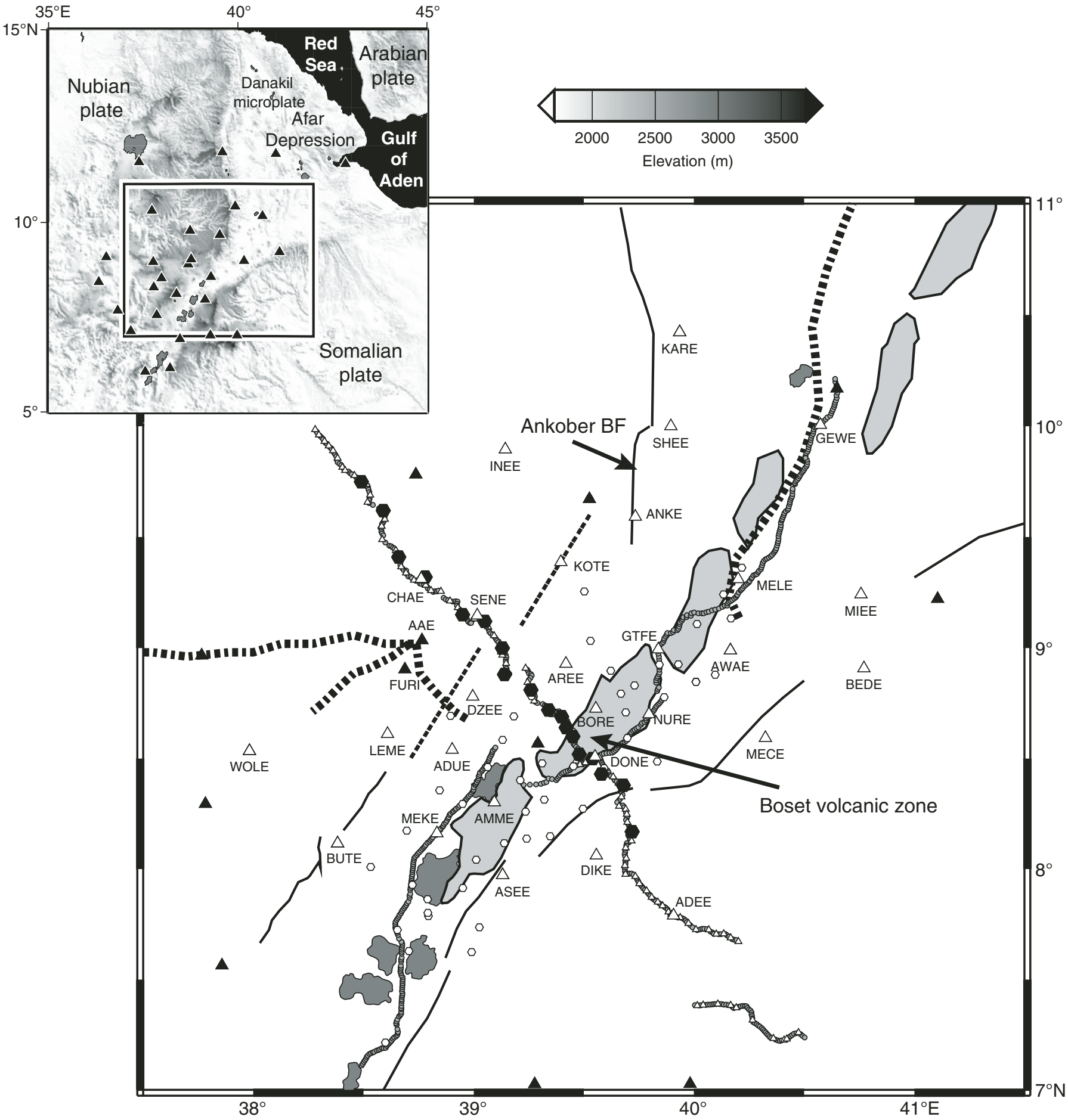

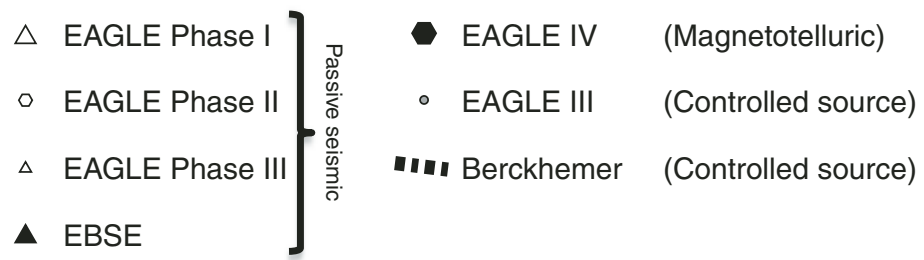

Figure 2. Location map of Ethiopia Afar Geoscientific Lithospheric Experiment (EAGLE) experiments. Mid-Miocene border faults and Quaternary magmatic zones are shown as in Figure 1. The EAGLE cross-rift wide-angle profile stations are directly beneath the colocated EAGLE III passive and EAGLE IV magnetotelluric stations. The "Berckhemer" lines are pre-EAGLE wide-angle profiles (Berckhemer et al., 1975). Inset: Regional tectonic setting on a topographic map with locations of EBSE (Ethiopia Broadband Seismic Experiment) broadband stations shown as triangles. BFBorder Fault. 
al., 2008). Bastow et al. (2008) resolved an 500-km-wide P- and S-wave low-velocity zone at 75 to $>400 \mathrm{~km}$ depth in the upper mantle that extends from close to the eastern edge of the Main Ethiopian Rift westward beneath the uplifted and flood basaltcapped NW Ethiopian Plateau (Figs. 3 and 4). Within the broad low-velocity region (LVR), zones of particularly low velocity are observed that have absolute delay times $\left(\delta t_{\mathrm{P}} \sim 4 \mathrm{~s}\right)$ indicating that the mantle beneath this region is amongst the slowest worldwide (see Poupinet, 1979). The observations are explained best by hypotheses involving high temperatures and partial melt beneath the Main Ethiopian Rift and adjacent NW Ethiopian Plateau. The S-wave model shows particularly low velocities at $75 \mathrm{~km}$ depth (Fig. 4B), probably indicating a larger portion of partial melt there (Bastow et al., 2005, 2008).

The lowest-velocity region appears not to be beneath southern/central Afar, but beneath the central part of the study area at $\sim 9^{\circ} \mathrm{N}, 39^{\circ} \mathrm{E}$ (Figs. 3 and 4). This observation is corroborated by observations of mean relative arrival-time residuals that do not suffer the same amplitude recovery problems as tomographic inversion. The abrupt increase in velocity north of $\sim 10.5^{\circ} \mathrm{N}$ coincides with an $\sim 20 \mathrm{~m} . \mathrm{y}$. increase in the time elapsed since the onset of plate stretching in Afar compared to the northern Main Ethiopian Rift (Bastow et al., 2008).

The Main Ethiopian Rift is located toward the eastern edge of the broad low-velocity structure, not above its center. This observation, along with strong correlations between lowestvelocity zones and lithospheric structures, suggests that preexisting structural trends and Miocene-to-Holocene rift tectonics strongly control melt migration at the base of the lithosphere (e.g., Bastow et al., 2005, 2008).

\section{Studies of Seismic Anisotropy}

Measurements of seismic anisotropy from teleseismic earthquakes can be used to infer patterns of strain and flow in the mantle (e.g., Vauchez et al., 2000). The anisotropy can be due to the lattice preferred orientation (LPO) of crystals or the preferred orientation of inclusions (e.g., oriented melt pockets $[\mathrm{OMP}])$ or periodic thin layering (PTL) of contrasting materials (e.g., Kendall, 2000). The resulting rock fabric produces a directional dependence in seismic velocities: seismic anisotropy. A shear wave in an isotropic medium will split into two shear waves when it encounters an anisotropic medium. The orientation of the shear waves and their difference in traveltimes constrain the symmetry and magnitude of the anisotropy. Seismic anisotropy can be measured using core phases such as SKS (for a review, see, e.g., Long and Silver, 2009). Such measurements offer good lateral resolution of anisotropy (e.g., Bastow et al., 2007) but poor vertical resolution. Seismic anisotropy also affects surface waves (Figs. 5 and 6). It leads to azimuthal variations in surface-wave phase velocities, discrepancies between Love-wave- and Rayleigh-wave-derived shear-wave velocity models, and particle motion anomalies (Kirkwood and Crampin, 1981). The dispersive nature of surface-wave propagation leads to good resolution of anisotropy variation with depth, but long wavelengths mean poor horizontal resolution compared to SKS studies. The analysis of anisotropy using a combination of seismic body and surface waves provides good vertical and horizontal resolution and offers information about length scales of anisotropy (e.g., Bastow et al., 2010). Local earthquake shear-wave splitting, if available, can also be used to constrain anisotropy above the earthquake hypocenter: typically, the upper crust in volcanic rift environments where the majority of earthquakes are relatively shallow (e.g., Barclay and Toomey, 2003; Crampin et al., 2008).

Analyses of regional surface waves in Ethiopia show sublithospheric fast shear waves coherently oriented in a northeastward direction from southern Kenya to the Red Sea (Debayle et al., 2001; Kendall et al., 2006). This parallels the trace of the deeper African superplume. The pattern of shear-wave anisotropy is more variable above depths of $150 \mathrm{~km}$. Analyses of splitting in teleseismic phases (SKS) and local shear waves within the rift valley consistently parallel trends of the Quaternary magmatic zones (Kendall et al., 2005, their Fig. 7; Keir et al., 2005). The magnitude of the splitting correlates with the degree of magmatism, and the polarizations of the shear waves align with magmatic segments along the rift valley (e.g., Ayele et al., 2004; Kendall et al., 2005, 2006). Analysis of surface-wave propagation across the rift valley confirms that anisotropy in the uppermost $75 \mathrm{~km}$ is due primarily to melt alignment (Figs. 6 and 7; Bastow et al., 2010), not LPO (flow)-type anisotropy. Away from the rift valley, the anisotropy agrees reasonably well with the preexisting Pan-African lithospheric fabric (e.g., Kendall et al., 2005; Gashawbeza et al., 2004). An exception is the region beneath the Ethiopian Plateau, where the anisotropy is variable and likely corresponds to preexisting fabric and ongoing meltmigration processes (Kendall et al., 2006).

\section{Receiver Functions}

Receiver functions can be used to capture P- to S-wave conversions at velocity contrasts in the receiver crust and mantle recorded in the P-wave coda from distant teleseismic earthquakes (e.g., Langston, 1979). They can be used to provide estimates of bulk crustal properties: crustal thickness $(H)$ and $\mathrm{V}_{\mathrm{P}} / \mathrm{V}_{\mathrm{S}}$ ratio (e.g., Zhu and Kanamori, 2000; Di Leo et al., 2009), which can then be related to bulk crustal composition via Poisson's ratio (e.g., Christensen, 1996; Chevrot and van der Hilst, 2000). Stuart et al. (2006) analyzed receiver functions in this way for EAGLE broadband stations, building on earlier work by Dugda et al. (2005). On the flanks of the rift, the crust on the Somalian plate to the east is $38-40 \mathrm{~km}$ thick. On the NW Ethiopian Plateau, the crust is thicker to the north $(41-43 \mathrm{~km})$ than to the south $(<40 \mathrm{~km})$; the thinning takes place over an off-rift upper-mantle low-velocity structure previously imaged by traveltime tomography (Bastow et al., 2005). The crust is slightly more mafic $\left(\mathrm{V}_{\mathrm{P}} / \mathrm{V}_{\mathrm{S}}>>1.85\right)$ on the NW plateau than on the SE plateau $\left(\mathrm{V}_{\mathrm{P}} / \mathrm{V}_{\mathrm{S}} \approx 1.80\right)$. This could be due to either magmatic activity or different prerift crustal compositions. Regions of volcanism on the side of the rift (e.g., SDFZ, Fig. 1) are characterized by thinned crust and a 

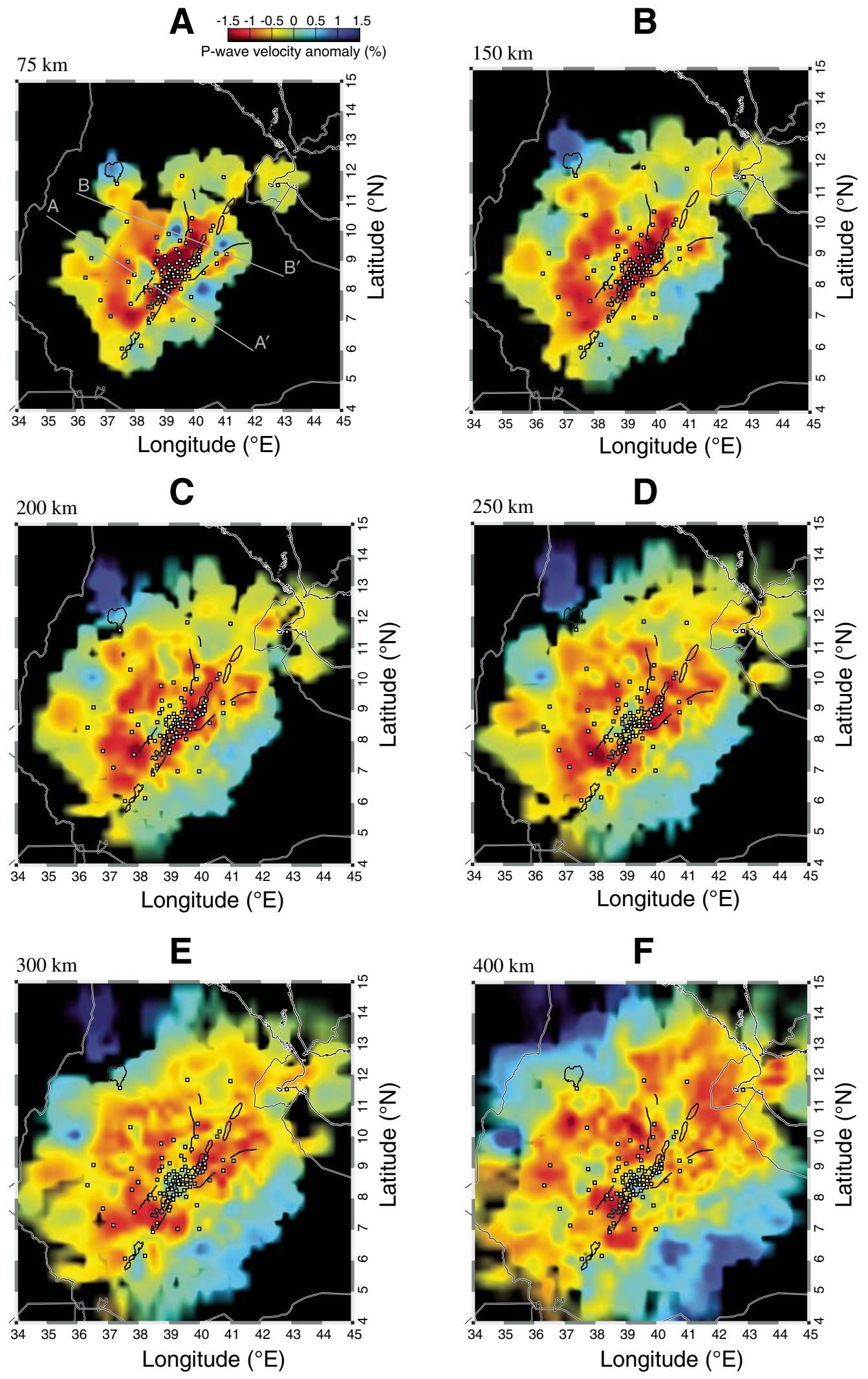

Figure 3. Depth slices through the P-wave velocity model at 75, 150, 200, 250, 300, and $400 \mathrm{~km}$ depth. The locations of the stations contributing to the tomographic inversions are shown by white squares. Figure is modified after Bastow et al. (2008). 

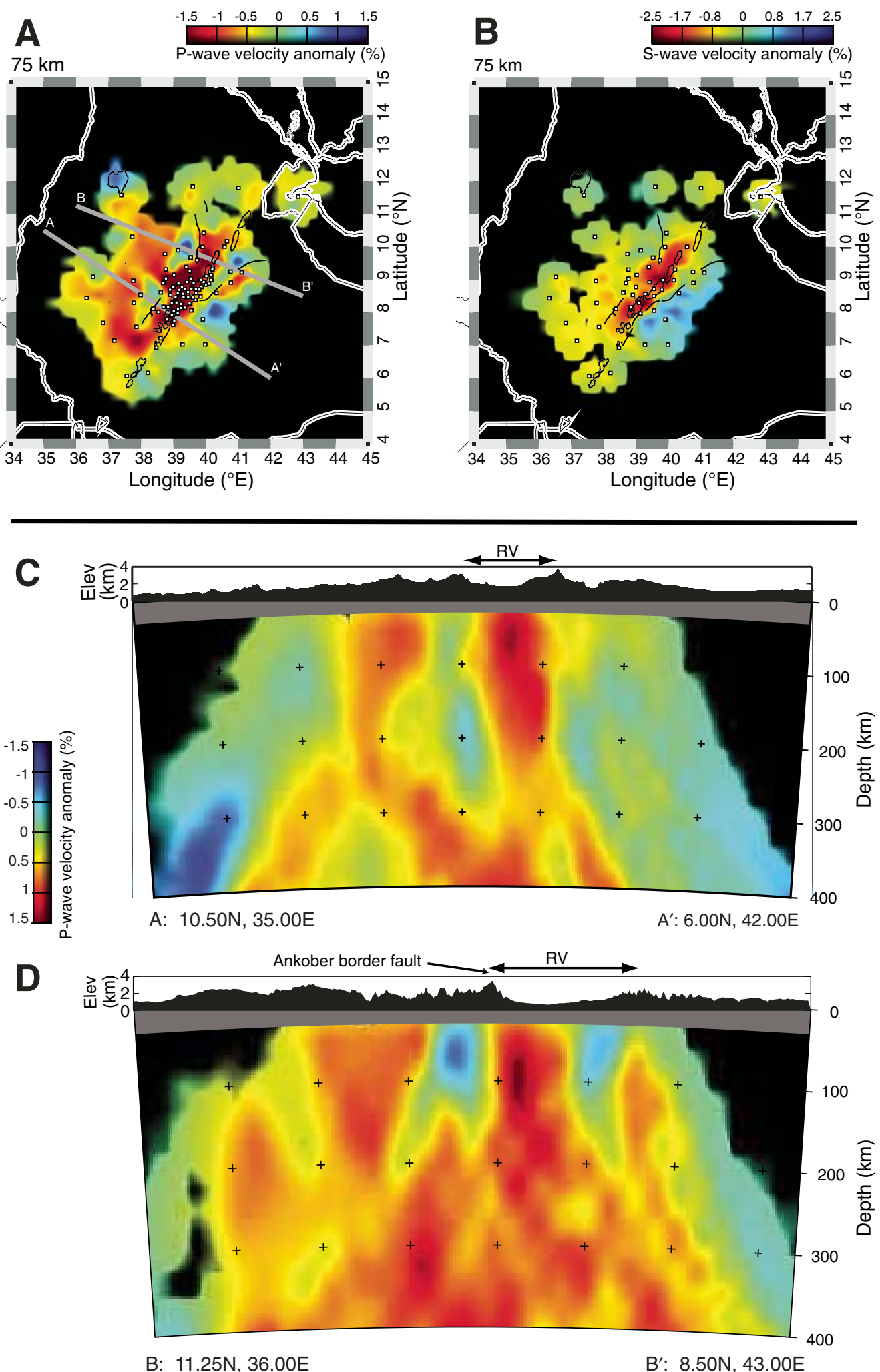

Figure 4. P- and S-wave seismic traveltime tomography for Ethiopia. (A-B) Comparison of P- and $\mathrm{S}$-wave velocity models at $75 \mathrm{~km}$ depth. (C) A-A': Vertical cross sections through the P-wave velocity model in the continental rifting part of the study area. (D) B-B': Cross section through southernmost Afar. Orientations of the cross sections are shown as gray lines in Figures 3A and 4A. Gray bands at the top of the cross sections obscure the view of the upper $30 \mathrm{~km}$ of the model space, where a lack of crossing rays prevents accurate recovery of velocity structure. RV-Rift Valley. Figure is modified after Bastow et al. (2008). 
$\mathrm{V}_{\mathrm{P}} / \mathrm{V}_{\mathrm{S}}$ ratio $>2.0$, indicative of partial melt within the crust. Within the rift, the $\mathrm{V}_{\mathrm{p}} / \mathrm{V}_{\mathrm{S}}$ ratio increases to greater than 2.0 (Poisson's ratio's $>0.33$ ) northward toward the Afar Depression. Such high values are once again indicative of partial melt in the crust and corroborate other geophysical evidence for increased magmatic activity as continental rifting evolves to oceanic spreading in Afar. Along the axis of the rift, crustal thickness varies from around $38 \mathrm{~km}$ in the south to $30 \mathrm{~km}$ in the north, with most of the change in Moho depth occurring just south of the Boset magmatic zone where the rift opens into the Afar Depression.

Of some debate in the receiver function literature is about the spatial extent of the underplate beneath the NW plateau. Keranen et al. (2009) argued that away from the wide-angle profile, the Moho is a sharper feature when observed with receiver functions than it appears using data from stations coincident with controlled-source wide-angle refraction Line 1 (Fig. 2). Stuart et al. (2006), in contrast, used forward modeling of receiver functions at station SENE on Line 1 (Fig. 2) and concluded that the receiver function method was sensitive to the top, not the bottom of the underplate. The spatial extent of this layer is therefore uncertain away from Line 1 on the NW plateau.

\section{Seismicity}

From October 2001 to February 2003, 1957 earthquakes occurred within the EAGLE passive network area (Fig. 8), and a selection of these was used for accurate location using a 3-D velocity model (Daly et al., 2008), focal mechanism determination (Keir et al., 2006b), and local earthquake splitting analysis (Keir et al., 2005). Border faults of the Main Ethiopian Rift are relatively inactive, except for clusters of seismicity at the intersections between the Main Ethiopian Rift and the older Red Sea and Gulf of Aden Rifts. Along the axis of the Main Ethiopian Rift, earthquakes are predominantly localized to depths of less than $\sim 15 \mathrm{~km}$ within 20-km-wide, right-stepping, en-echelon zones of Quaternary volcanism and faulting. Seismicity in these zones is characterized by low-magnitude $\left(\mathrm{M}_{\mathrm{L}} \sim 1-4\right)$ clusters (Keir et al., 2006a) coincident with Quaternary faults, fissures, and chains of eruptive centers. All but three focal mechanisms show normal dip-slip motion; the minimum compressive stress is $\mathrm{N} 103^{\circ} \mathrm{E}$, perpendicular to Quaternary faults and aligned volcanic cones (Fig. 8A). The seismogenic zone lies within and above the 20-km-wide zone of dense mafic intrusions: Strain localization through magmatism in the mid-upper crust most likely controls
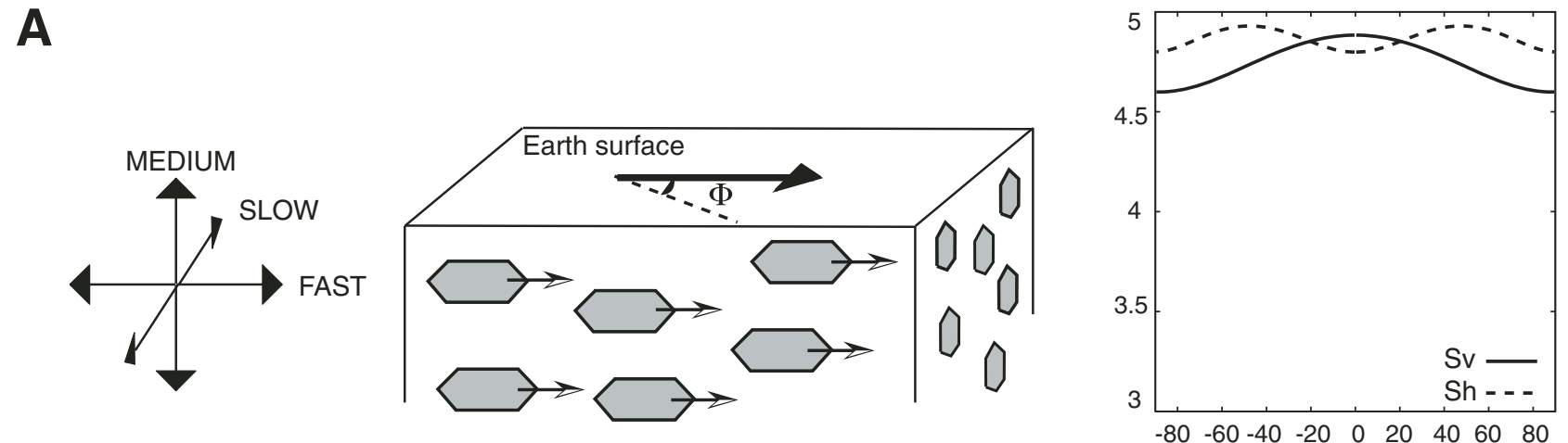

Azimuth, $\Phi$ (degrees from flow direction)

B
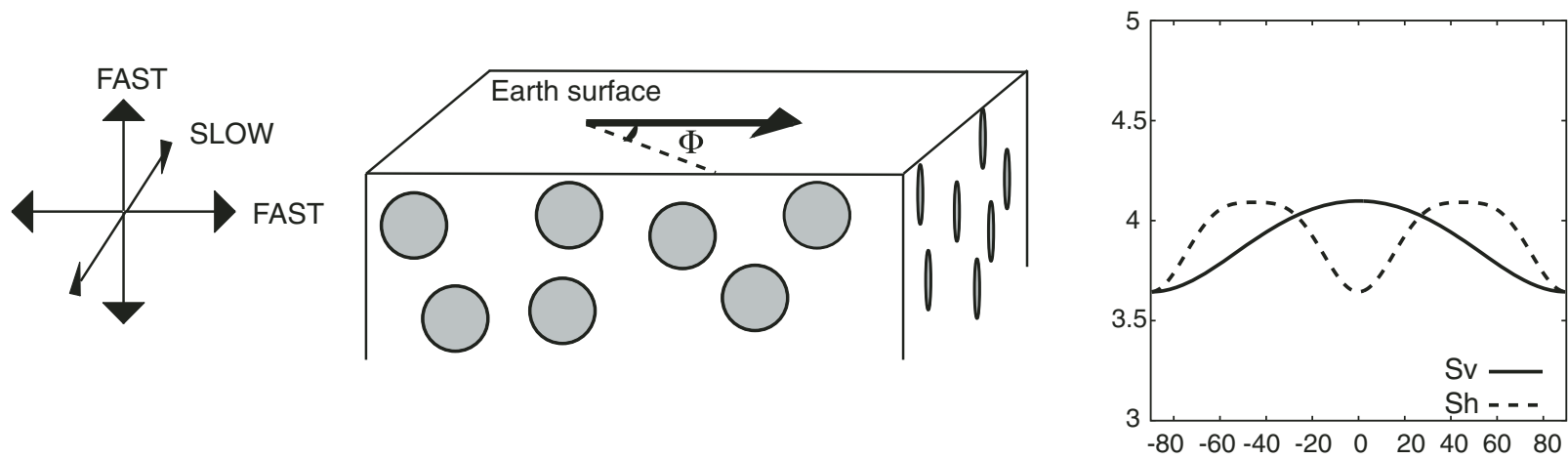

Azimuth, $\Phi$ (degrees from symmetry plane)

Figure 5. Mechanisms for seismic anisotropy. (A) Anisotropy due to lattice preferred orientation (LPO) of upper-mantle minerals. Top left shows directions of fast, slow, and medium P-wave velocities, assuming a horizontal flow direction and a vertical flow plane as shown in the cartoon (middle). Top right shows azimuthal variations in vertically and horizontally polarized shear waves $\left(\mathrm{S}_{\mathrm{V}}\right.$ and $\left.\mathrm{S}_{\mathrm{H}}\right)$. (B) Anisotropy due to oriented melt pockets (OMP). Melt volume fraction is assumed to be $0.1 \%$, and the melt lies in disk-like pockets (oblate spheroids) with an aspect ratio of 0.02. Figures are modified after Bastow et al. (2010). 
the formation and continued growth of narrow axial rift grabens in the overlying seismogenic zone.

A minor cluster of anomalously deep (20-35 km) low-magnitude earthquakes underlies distinctive chains of aligned volcanoes on the western margin of the Main Ethiopian Rift. The cluster of deep earthquakes also coincides with a zone of particularly high conductivity (attributed to presence of fluids such as partial melt and hydrous fluids; Whaler and Hautot, 2006; Whaler, 2006) in the lower crust, which is positioned directly above the slowest-velocity P-wave uppermost mantle (Keir et al., 2009b). These lowercrustal earthquakes are interpreted as related to either the emplacement of magma or release of fluids during magma crystallization (Keir et al., 2009b).
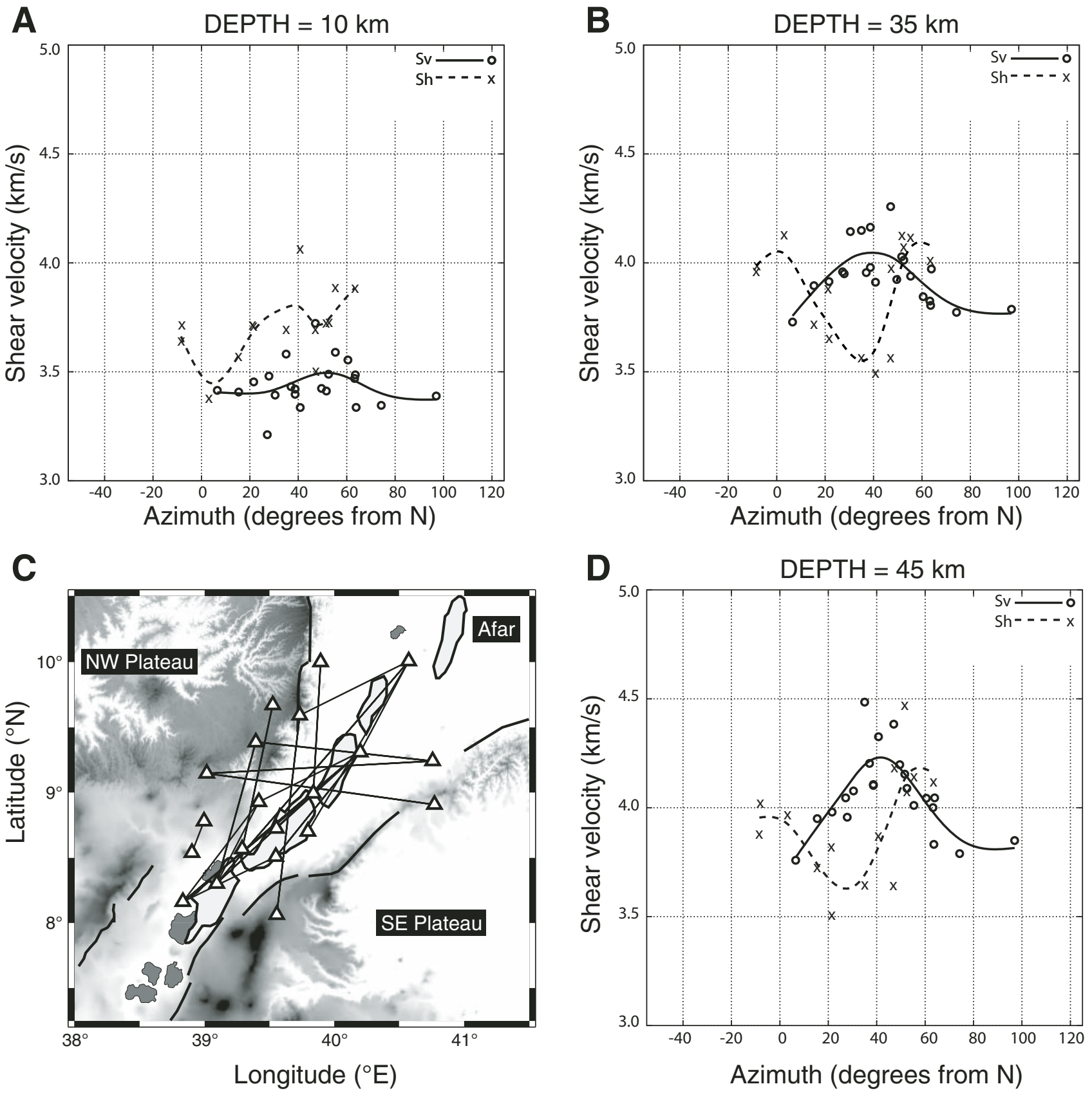

Figure 6. Surface-wave anisotropy within the Main Ethiopian Rift. Azimuthal variation in $\mathrm{S}_{\mathrm{V}}$ and $\mathrm{S}_{\mathrm{H}}$ wave speeds at depths of (A) $10 \mathrm{~km}$, (B) $35 \mathrm{~km}$, and (D) $45 \mathrm{~km}$. Solid lines are natural smooth spline fits to individual measurements, and azimuth is measured clockwise from north. Estimates are made from group velocity measurements of local events and interstation phase velocity measurements. (C) Interstation paths for phase velocity measurements. Figures were modified after Bastow et al. (2010). 

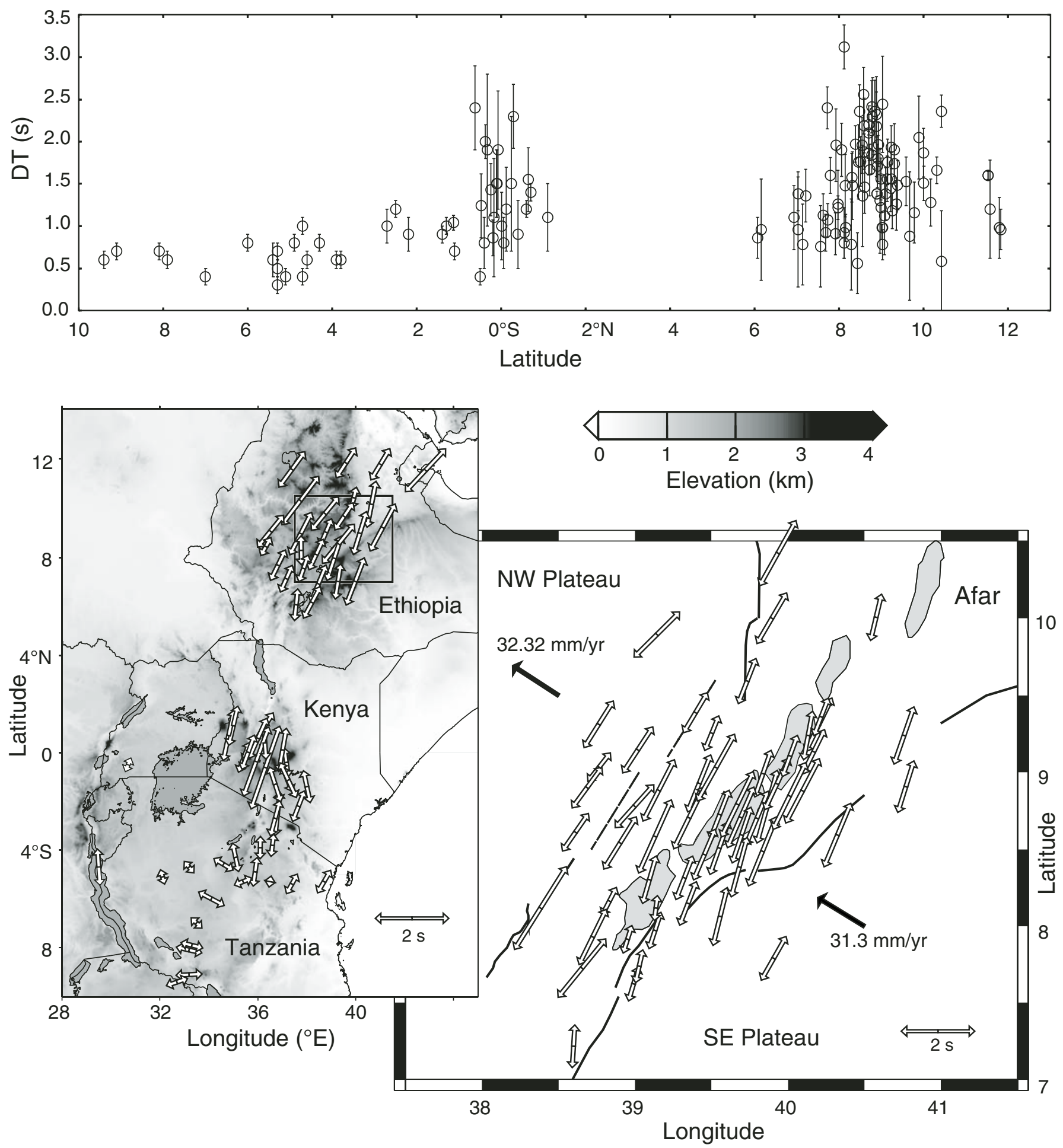

Figure 7. SKS splitting measurements along the East African Rift. Lower right shows detail from Main Ethiopian Rift. Mid-Miocene border faults and monoclines are marked with solid and dashed lines, respectively. Large arrows indicate absolute plate motion. Quaternary magmatic zones are shaded in red. In both maps, arrows show orientation of fast shear wave, and length of arrow is proportional to magnitude of splitting. Top figure shows SKS splitting delays $(\delta t)$ as a function of latitude. Figure is modified after Kendall et al. (2006). 


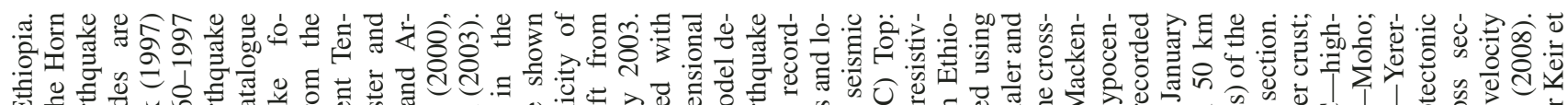

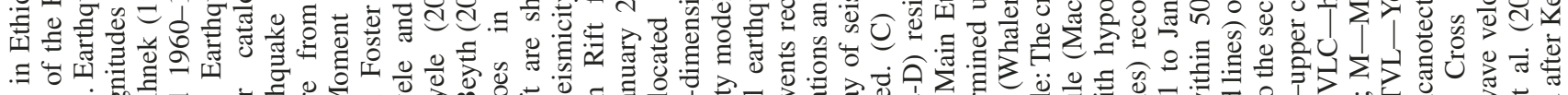

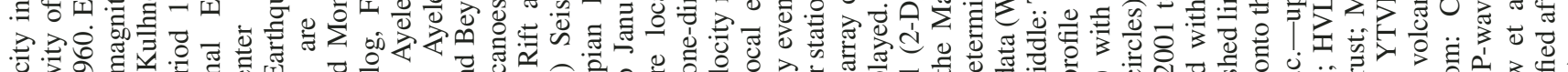

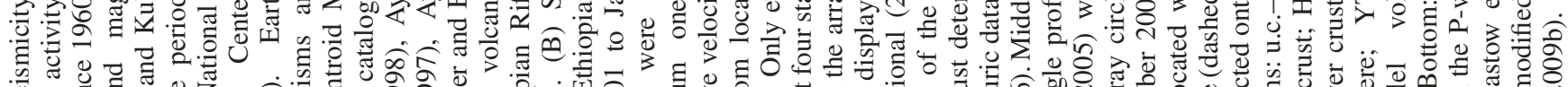

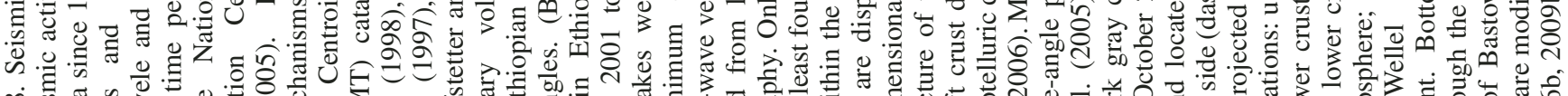

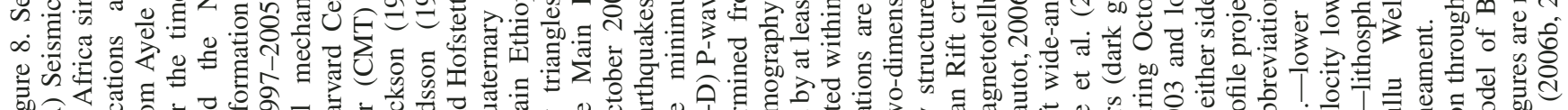

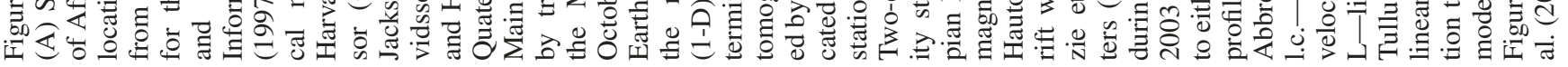
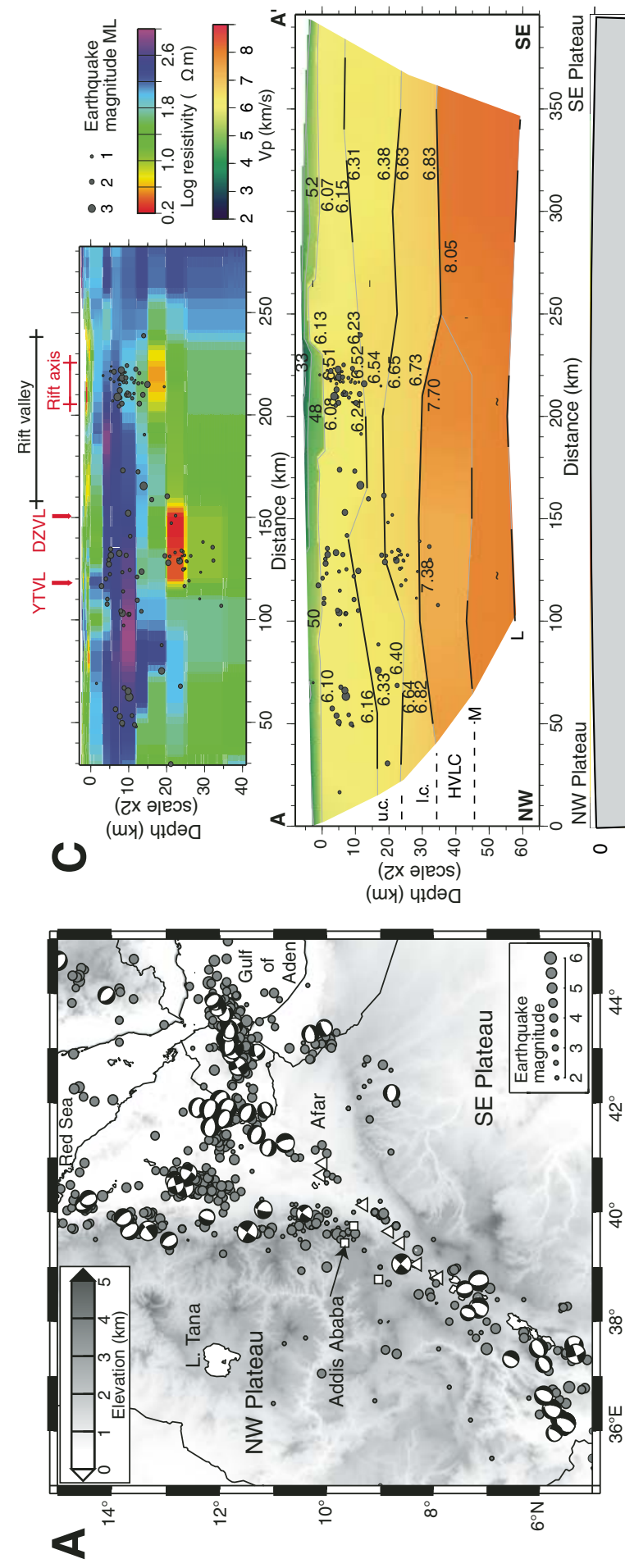
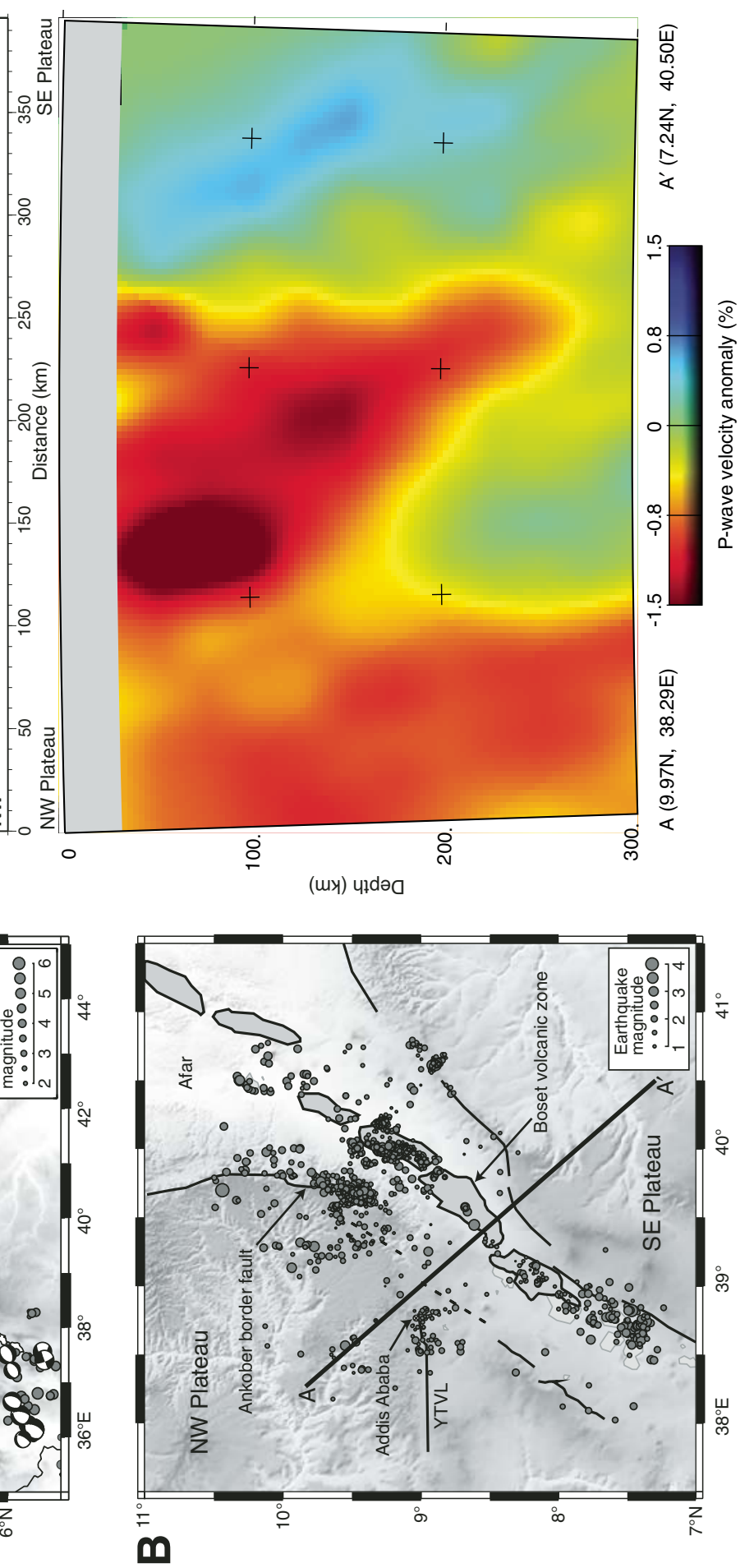
Despite the focus of EAGLE on the Main Ethiopian Rift, the most significant regional seismic activity occurred during August 2002 on the western flank of the Red Sea Rift near the border between Ethiopia and Eritrea. Over a period of 2 wk following 7 August 2002, 75 earthquakes of $M_{L}$ 2.1-5.6 were located using combined data from EAGLE and permanent stations in Ethiopia and Eritrea (Ayele et al., 2007b). Moment tensor inversion on a selection of data is consistent with earthquakes being 5-7 km deep and normal slip on NNW-striking faults, parallel to the predominant structures mapped at the surface. The well-constrained cluster of earthquakes, combined with macroseismic reports of ground shaking in the city of Mekele (Fig. 1), shows that the grabens on the heavily populated western Afar margin pose a significant seismic hazard. Indeed, historical records of macroseismic destruction at other localities on the western Afar margin such as Kara Kore (1961) and Ankober (Fig. 1) (1841-1842) (Gouin et al., 1979), combined with the recent study during EAGLE advise the Ethiopian government to enforce building codes for earthquake-resistant structures.

\section{Crustal Tomography}

Using the local earthquake catalog of Keir et al. (2006b), Daly et al. (2008) presented 3-D P-wave velocity and $\mathrm{V}_{\mathrm{P}} / \mathrm{V}_{\mathrm{S}}$ models of the midcrust (Fig. 9). The models show high P-wave velocities $(6.5 \mathrm{~km} / \mathrm{s})$ beneath the axis of the rift at a depth of $12-25 \mathrm{~km}$, consistent with the findings of Keranen et al. (2004), who found high P-wave velocities $(6.5-6.8 \mathrm{~km} / \mathrm{s})$ at $7-15 \mathrm{~km}$ depth using tomographic inversion of the controlled-source traveltime data set. The presence of high $\mathrm{V}_{\mathrm{p}} / \mathrm{V}_{\mathrm{S}}$ ratios $(1.81-$ 1.84) at 12-25 km, segmented positive Bouguer anomalies (Mahatsente, et al., 1999; Tiberi et al., 2005; Mickus et al., 2007), and coincidence with zones of surface Quaternary volcanism suggest that the higher-velocity, higher-density zones are cooled dense mafic intrusions. The high $\mathrm{V}_{\mathrm{P}} / \mathrm{V}_{\mathrm{S}}$ values, along with other geophysical evidence, suggest that magmatic processes continue to the present day.

\section{Controlled-Source Profiles}

A major component of EAGLE was a controlled-source wide-angle experiment, which consisted of one cross-rift (Line 1) and one rift-axial (Line 2) profile (both $\sim 400 \mathrm{~km}$ ) and an $\sim 100$-km-diameter two-dimensional (2-D) array (Fig. 2) to provide 3-D subsurface images beneath the Boset volcano where the profiles intersected (Mackenzie et al., 2005; Maguire et al., 2006).

Twenty-three explosive charges, with an average shot size of $1100 \mathrm{~kg}$, were detonated in boreholes up to $50 \mathrm{~m}$ deep, in two lakes, and in two quarries. Approximately 1000 single-channel "Texan" geophones spaced at $\sim 1 \mathrm{~km}$ along the $400 \mathrm{~km}$ profiles and $\sim 2.5 \mathrm{~km}$ within the 2-D array recorded the shots simultaneously with a 93 Güralp CMG-6TD three-component broadband deployment using $\sim 5 \mathrm{~km}$ station spacing along Line 1 (Fig. 2). Further details of the wide-angle deployment and raw data qual- ity are available in Mackenzie et al. (2005) and Maguire et al. (2006), but the final analyses of these data are shown here in Figure 10. Some key features of the profiles are as follows:

The $6.5 \mathrm{~km} / \mathrm{s}$ high-velocity bodies in the upper crust beneath the rift axis are noted in Line 1 (Fig. 10A).

The $6.1-6.4 \mathrm{~km} / \mathrm{s}$ upper crust is $\sim 28 \mathrm{~km}$ thick beneath the NW and SE plateaus. It then thins to $\sim 23 \mathrm{~km}$ beneath the Main Ethiopian Rift. Along Line 2 (Fig. 10B), upper-crust thickness falls to $\sim 8 \mathrm{~km}$ in Afar, and the most dramatic thinning occurs across the Boset magmatic zone of the Main Ethiopian Rift.

The $6.6-7.1 \mathrm{~km} / \mathrm{s}$ lower crust on Line 1 is $\sim 14 \mathrm{~km}$ thick on the SE plateau and 9-12 km thick beneath the NW plateau. Lower-crustal thickness is relatively uniform at $\sim 16-20 \mathrm{~km}$ along Line 2.

Beneath Line 1, the lower crust overlies an anomalous $\sim 8-15-\mathrm{km}$-thick layer of velocity $\sim 7.38 \mathrm{~km} / \mathrm{s}$ on the NW plateau; this feature is absent from the east.

The NW plateau crust is underlain by a $£ 8.0 \mathrm{~km} / \mathrm{s}$ mantle, while the SE plateau uppermost mantle is characterized by "normal" mantle velocities of $\sim 8.05 \mathrm{~km} / \mathrm{s}$.

Mantle reflectors occur at 50-60 km beneath large portions of Lines 1 and 2 but shallow considerably to $\sim 40 \mathrm{~km}$ beneath the northernmost part of Line 2.

The results from crustal seismic tomography using the 2-D array (Keranen et al., 2004) also indicate the presence of P-wave high-velocity bodies beneath Boset, as well as other regions of the Wonji fault belt (Fig. 11).

\section{Gravity and Magnetotelluric Surveys}

The interpretation of gravity anomalies, like other potential field data, suffers from nonuniqueness. However, in conjunction with controlled-source seismic data (which can be used to add geometric constraints during modeling), gravity data become a powerful tool for constraining the physical properties of the lithosphere. Cornwell et al. (2006) conducted a cross-rift gravity survey coincident with wide-angle Line 1 (Fig. 2). Data from 72 stations across the Main Ethiopian Rift were forward and inverse modeled for density structure to a depth of $\sim 60 \mathrm{~km}$ using starting models defined by the seismic results of Mackenzie et al. (2005) and Keranen et al. (2004) (Figs. 10 and 11). The starting model provided a good first-order fit to the data, but the sensitivity of the gravity method to lateral density changes enabled improved definition of structure. Figure 12 shows the final model, which has the following salient features:

The upper-mantle density beneath the NW rift flank has to be reduced to $3290 \mathrm{~kg} / \mathrm{m} 3$ to fit the observed anomaly.

An axial low-density upper-mantle or high-density lowercrustal zone is modeled as a $\sim 50-\mathrm{km}$-wide body with a density of $3190 \mathrm{~kg} / \mathrm{m} 3$.

Two high-density (3000 kg/m3) upper-crustal bodies underlie the Main Ethiopian Rift: a 20-km-wide axial body, and a 12-km-wide off-axis body, both of which are most likely to be gabbroic in composition. 

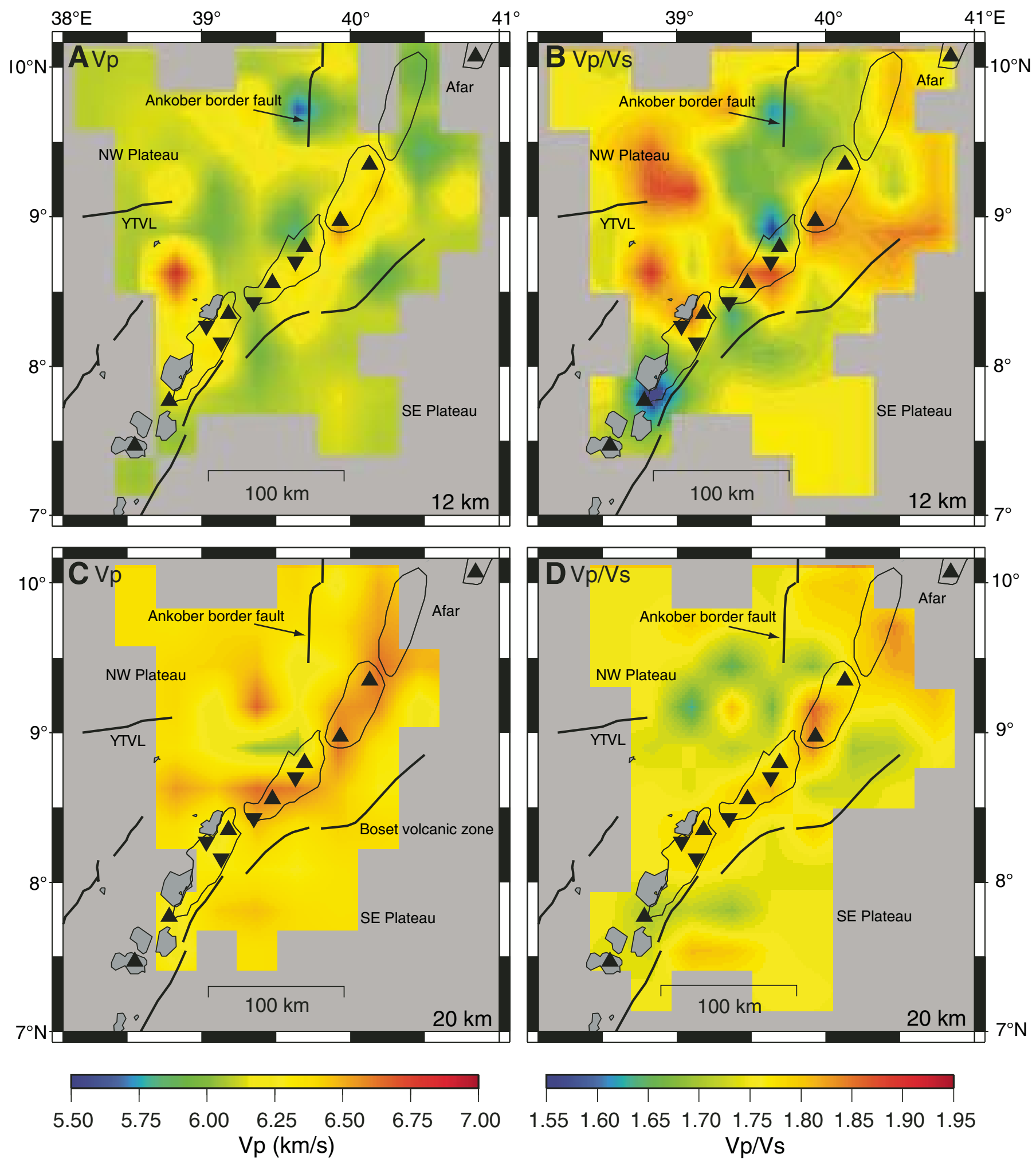

Figure 9.12 and $20 \mathrm{~km}$ depth slices through the three-dimensional (3-D) P-wave velocity and $\mathrm{V}_{\mathrm{P}} / \mathrm{V}_{\mathrm{S}}$ ratio models. YTVL-Yerer-Tullu Wellel volcanotectonic lineament. Figure is modified after Daly et al. (2008). 


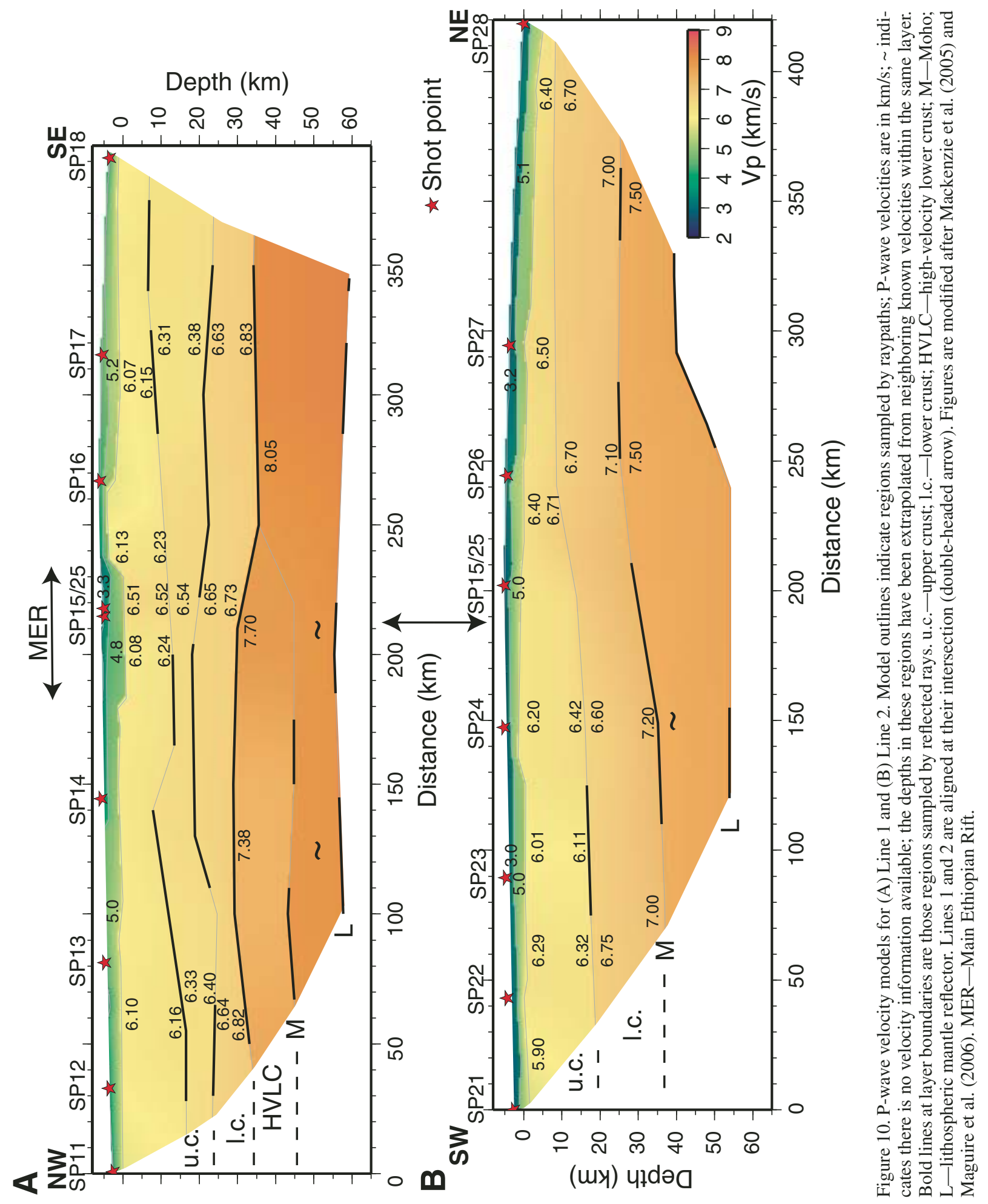


A $<10-\mathrm{km}$-wide high-density $(2850 \mathrm{~kg} / \mathrm{m} 3)$ body lies directly beneath Boset.

The high-velocity lower-crust/low-velocity upper-mantle low-velocity layer seen in wide-angle Line 1 is characterized by a $3170 \mathrm{~kg} / \mathrm{m} 3$ layer, which is absent from the east.

Coincident with the wide-angle Line 1 and the gravity survey (Fig. 2), Whaler and Hautot (2006) carried out a magnetotelluric profile to investigate the electrical conductivity structure of the crust beneath the Main Ethiopian Rift and adjacent plateaus. The resulting model, shown in Figure 8C, has several key features:
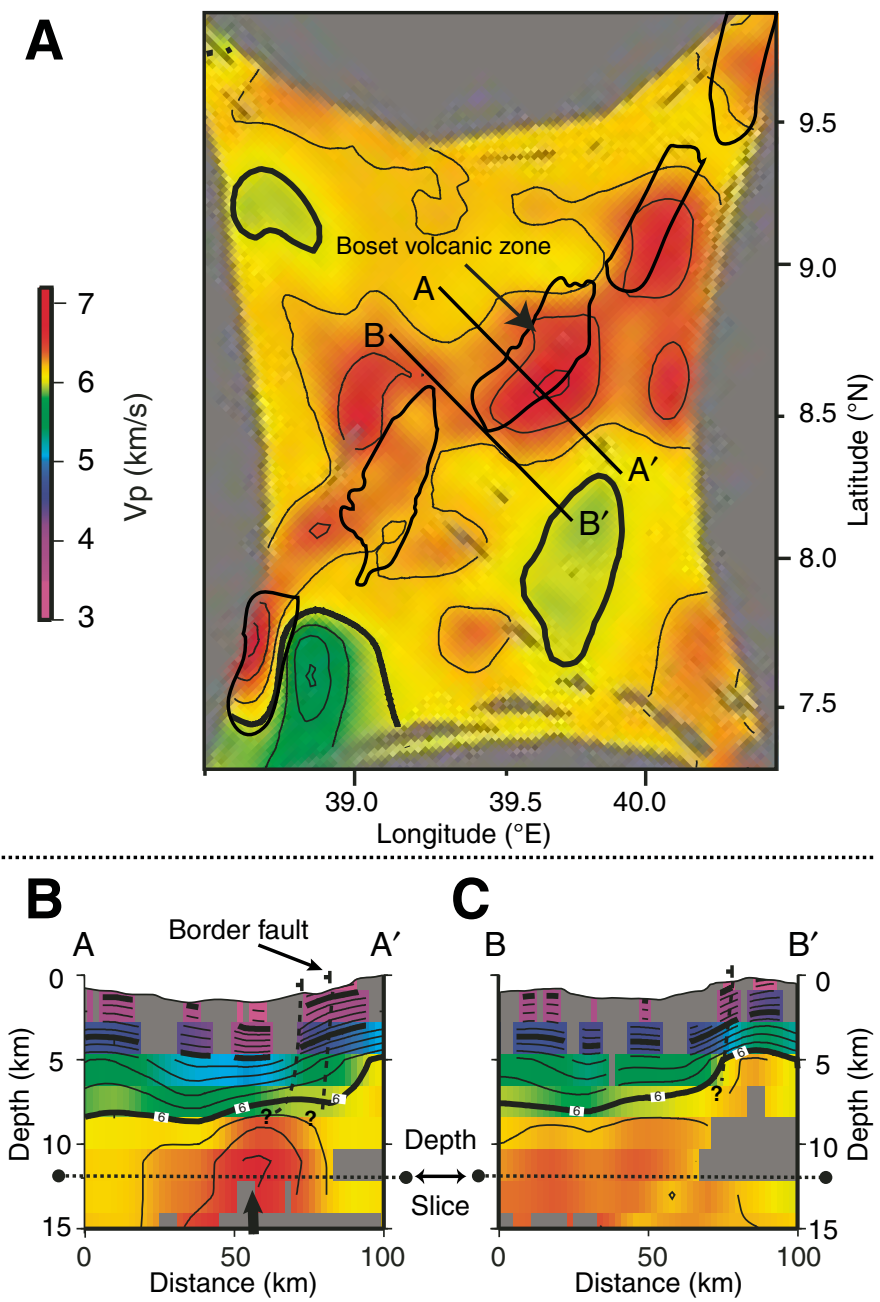

Figure 11. Controlled-source seismic tomography. (A) Horizontal slice $10 \mathrm{~km}$ beneath the two-dimensional (2-D) controlled-source array. The thick contour lines mark $6.0 \mathrm{~km} / \mathrm{s}$, with minor contours at $0.2 \mathrm{~km} / \mathrm{s}$ intervals. High-velocity bodies (red) are interpreted as solidified magmatic intrusions beneath the rift. (B) Rift-perpendicular cross-section A- $\mathrm{A}^{\prime}$ extending through the Boset magmatic field. High-velocity $\left(\mathrm{V}_{\mathrm{p}}\right)$ body (vertical arrow) beneath the rift valley is interpreted as a solidified mafic intrusion into Precambrian basement. (C) B-B' shows riftperpendicular section between magmatic segments. Fault symbols and proposed subsurface continuation of faults (dashed lines) are marked. Areas of no ray coverage are gray. Figure is modified after Keranen et al. (2004).
A shallow conductive lens at $<1 \mathrm{~km}$ depth underlies the Boset Volcano (Fig. 1).

Deeper conductive material beneath Boset extends to at least lower-crustal depths.

A second, highly conductive layer underlies rift flank to the east of Addis Ababa at 20-25 km depth (at 120-150 km along the magnetotelluric profile).

The lowermost crust and uppermost mantle of the NW plateau, though not well resolved, is more conductive than to the SE of the Somalian plate.

\section{DISCUSSION}

In this section, we summarize the main conclusions of the EAGLE experiments and show, with reference to other studies (e.g., geochemistry and geodynamics), how they have advanced our understanding of both hotspot tectonism and continental breakup processes.

\section{Hotspot Tectonism and the Ethiopian Low-Velocity Anomaly}

The most detailed P- and S-wave seismic tomographic images to date (Figs. 3 and 4) of the upper mantle in Ethiopia are presented by Bastow et al. (2008); they corroborate a growing body of evidence that Ethiopia is underlain by a broad $(\sim 500-\mathrm{km}$ wide) low-velocity zone (e.g., Debayle et al., 2001; Grand, 2002; Ritsema and Allen, 2003; Benoit et al., 2006a, 2006b; Li et al., 2008) that connects to the deeper African superplume in the lower mantle. There is no evidence for a narrow $(\sim 100-200-\mathrm{km}$ diameter) plume tail beneath Ethiopia, as would be expected if a starting plume existed today (e.g., Hawaii; Wolfe et al., 2009), although the assumption that such a feature would be illuminated by seismic tomography proceeds on the assumption that thermal effects are the dominant cause of heterogeneity. On the contrary, absolute delay times at permanent station AAE (Fig. 2), which indicate the mantle beneath Ethiopia is amongst the slowest worldwide (e.g., Poupinet, 1979; Bastow et al., 2005, 2008), suggest strongly that high temperatures and the presence of partial melt are necessary to explain the seismic observations.

Within the broad low-velocity anomaly, the lowest-velocity zones, interpreted as zones of enhanced partial melt, are located at $\sim 9^{\circ} \mathrm{N}$ in the Main Ethiopian Rift, not beneath southern Afar (Bastow et al., 2008). New experiments in Afar will illuminate the crust and mantle there and help reconcile this finding with the results of many global tomographic studies, but it is unclear whether the intense LVR has resulted from focused mantle upwelling (resulting, for example, from a steeper lithosphereasthenosphere boundary at this latitude compared to the more extended Afar region, where melt may be less focused; e.g., Bastow et al., 2005, 2008) and/or enhanced decompressional melting at this latitude, where the Main Ethiopian Rift is younger than the East African Rift to the south and Afar to the north (which was largely formed during the rifting of Arabia from Africa at 
ca. $30 \mathrm{Ma}$ ). Kinematic rifting models indicate that rapid lithospheric thinning can result in decompressional melting of the underlying mantle (e.g., Bown and White, 1995). Rifting over longer periods, however, greatly reduces melt volumes, as heat is lost through conduction. Such ideas, coupled with greater depletion of the subcontinental lithospheric mantle beneath Afar, could explain the seismic observations, with larger melt volumes pro- ducing the lower velocities in the Main Ethiopian Rift (Bastow et al., 2008, 2010).

Whatever the model for rifting in Ethiopia, the results from the seismic tomography studies provide clear evidence for an abundant source of partial melt in the mantle. In the following section, we present evidence to suggest that this melt source plays a vital role in the ongoing rifting process in Ethiopia.
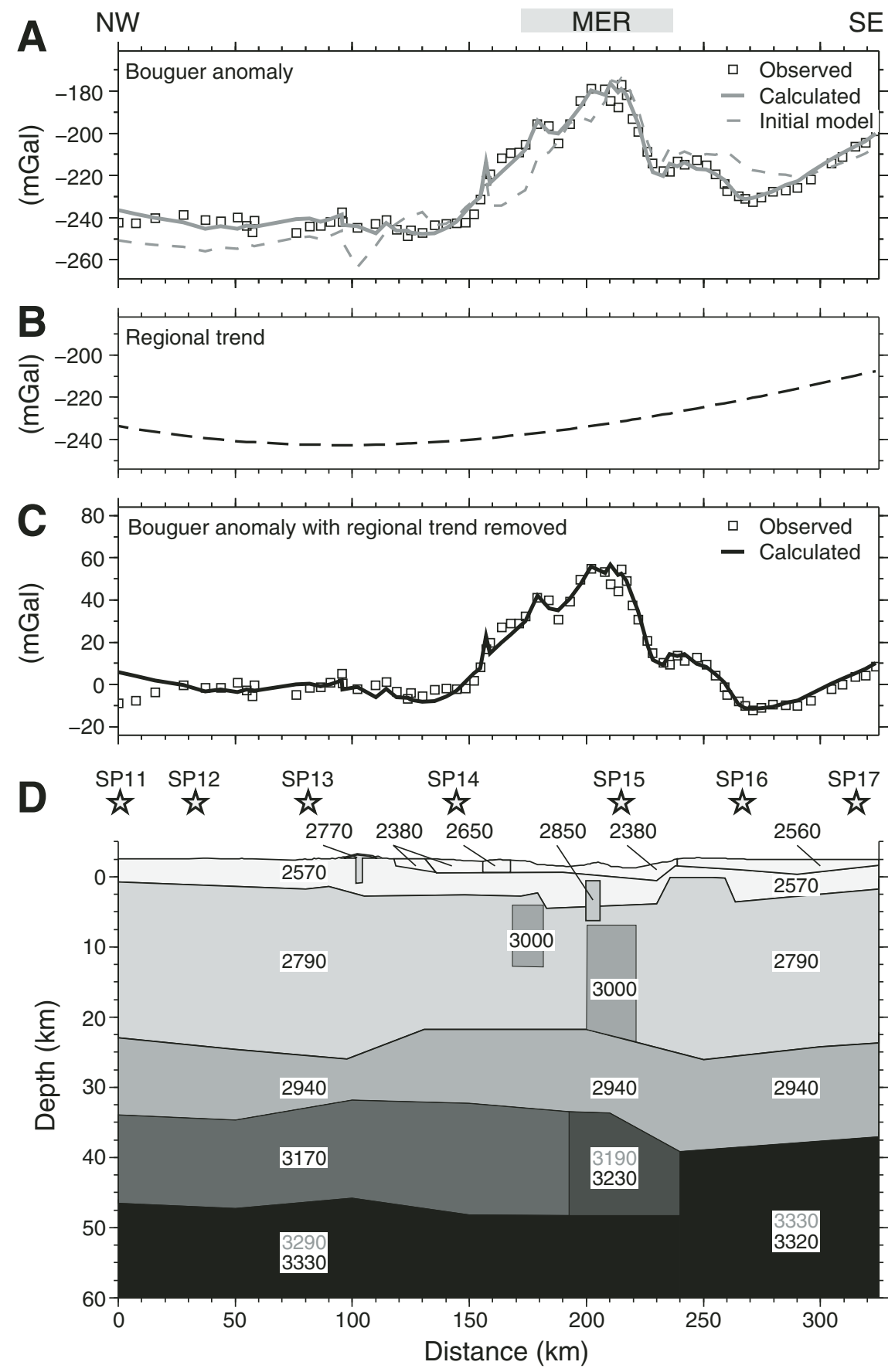

Figure 12. (A) Calculated final (solid line) and initial (dashed line) Bouguer anomaly compared with observed Bouguer anomaly (squares) along the Ethiopia Afar Geoscientific Lithospheric Experiment (EAGLE) cross-rift profile. MER-Main Ethiopian Rift. (B) Regional long-wavelength trend from lowpass filtering (i.e., wavelengths more than $\sim 80 \mathrm{~km}$ ) of existing Ethiopian gravity data (e.g., Mahatsente et al., 1999; Tiberi et al., 2005). (C) Calculated Bouguer anomaly (solid line) and observed Bouguer anomaly with regional trend subtracted (squares). (D) Final density model (values in $\mathrm{kg} / \mathrm{m}^{3}$ ). Where two density values are labeled for a particular layer, the upper corresponds to the calculated anomaly in A and the lower corresponds to the calculated anomaly in C. Stars are the locations of the seismic shot points. Figure is modified after Cornwell et al. (2006). 
Rifting in Ethiopia: Geophysical Studies of Crustal Structure and Process

An aim central to EAGLE was to understand better how strain is partitioned between magma intrusion and fault slip along the axis of the Main Ethiopian Rift. Geodetic data indicate that $\sim 80 \%$ of present-day strain in the Main Ethiopian Rift is accommodated within the Main Ethiopian Rift, not on midMiocene border faults (Bilham et al., 1999; Bendick et al., 2006). Ebinger and Casey (2001) proposed that the locus of strain since ca. $12 \mathrm{Ma}$ has migrated away from mid-Miocene border faults to en-echelon chains of Quaternary magmatic segments (Figs. 1 and 2) in the Wonji fault belt. Crustal-scale imaging by EAGLE offered a unique opportunity to test this hypothesis.

The relatively unfaulted flanks of the rift zone are underlain by crust of thickness $40-45 \mathrm{~km}$, and yet most of the region was below sea level in Paleocene times. Thus, much of the plateau uplift can be explained by crustal intrusion associated with the flood basaltic magmatism in Eocene-Oligocene times. Crossrift wide-angle profiles (Fig. 10) image mafic intrusions beneath the zones of Quaternary magmatism, calibrating the crustal tomography (Fig. 11; Keranen et al., 2004; Fig. 9; Daly et al., 2008) and gravity anomaly studies (Fig. 12; Cornwell et al., 2006). Despite the relatively small reduction in crustal thickness from rift shoulders (40-48 km) to the rift axis (40-26 km), strain has localized to a zone of magma intrusion and minor faulting that is less than $20 \mathrm{~km}$ in width. In addition to axial magmatism, the presence of high conductivities and coincident anomalously deep earthquakes beneath chains of volcanoes near the rift margin support ongoing off-axis emplacement of magma into the lower crust (Fig. 8). These observations are consistent with those from passive margins worldwide: Magmatic margins have a narrow, relatively thick ocean-continent transition zone compared to wide, highly attenuated, amagmatic margins (e.g., Hopper and Buck, 1993).

The along-axis wide-angle seismic profile shows a southto-north decrease in crustal thickness from $\sim 40 \mathrm{~km}$ in the SW to $\sim 26 \mathrm{~km}$ in the NE beneath Afar (Fig. 10N). The accompanying increase in upper-crustal $\mathrm{V}_{\mathrm{P}}$ has been interpreted as evidence for an increased volume of intruded gabbroic material during extension toward full incipient seafloor spreading. Tomographic inversions of active and passive source seismic data by Keranen et al. (2004) and Daly et al. (2008) also have confirmed the presence of elevated seismic velocities to $~ 20-30 \mathrm{~km}$ depth beneath many areas of Quaternary volcanism in the Main Ethiopian Rift (Figs. 9 and 11). Zones of higher-velocity and higher-density (Fig. 12) anomalies correspond to the surface expression of Quaternary magmatism within the Ethiopian Rift. This, in combination with the lack of crustal thinning, suggests that an $~ 20-30-\mathrm{km}$-wide zone of mafic intrusions beneath the rift axis accommodates the majority of strain in the midcrust.

During Miocene-Pliocene times, large offset border faults accommodated the largest proportion of strain across the Ethiopian Rift. However, since Pliocene times, extension in the upper crust has been accommodated by a combination of dikes and normal faults within the Main Ethiopian Rift (e.g., Keranen et al., 2004; Keir et al., 2006b). The marked coincidence between narrow, seismically active (Keir et al., 2006b) Quaternary rift-axial grabens containing aligned volcanic cones and fissural flows, and mid- to upper-crustal zones of mafic intrusions suggests that the locus of brittle failure in the upper crust is controlled by dike intrusion both within and beneath the seismogenic zone. The EAGLE results therefore point toward a model of magma-assisted rifting in Ethiopia, where magma intrusion throughout the lithosphere dominates over mechanical stretching to accommodate extension through localized axial diking (e.g., Buck, 2004, 2006).

The presence of magma in the crust beneath the regions of Quaternary rift magmatism and the uplifted rift shoulders is indicated not only by recent volcanism in the region (e.g., Rooney et al., 2005, 2007), but also by high $\mathrm{V}_{\mathrm{p}} / \mathrm{V}_{\mathrm{S}}$ ratios in the crust. This has been observed both on the bulk crustal scale by analyses of teleseismic receiver functions (e.g., Dugda et al., 2005; Stuart et al., 2006), and also by shallower analysis of local seismicity data (e.g., Daly et al., 2008). Magnetotelluric data are more sensitive to the presence of melt than seismic methods. The high conductivity anomalies (Fig. 8C) beneath the rift axis in the upper $\sim 2 \mathrm{~km}$ and at $15-20 \mathrm{~km}$ depth provide the most compelling geophysical evidence for the presence of partial melt in the crust beneath the rift (e.g., Whaler and Hautot, 2006).

A recurring theme amongst many EAGLE studies is the asymmetry of the Main Ethiopian Rift with respect to the underlying mantle low-velocity body (e.g., Bastow et al., 2008). Mackenzie et al. (2005), Maguire et al. (2006), Stuart et al. (2006), and Cornwell et al. (2006) all have presented evidence for the presence of a $15-\mathrm{km}$-thick high-velocity $(\mathrm{Vp} \approx 7.38 \mathrm{~km} / \mathrm{s})$, dense $\left(3170 \mathrm{~kg} / \mathrm{m}^{3}\right)$ lower-crustal layer, which they interpreted to be underplated material emplaced at the time of continental flood basalt eruption (ca. 45-30 Ma) and modified by subsequent Miocene-to-Holocene rifting in the Main Ethiopian Rift. Recent analyses of earthquake data in Ethiopia also highlight the absence of seismicity on the Somalian plate (SE) and its relative abundance on the Nubian plate (NW; Keir et al., 2009b). In places, seismicity on the NW side of the Main Ethiopian Rift is anomalously deep and most likely caused by ongoing magmatic processes (Fig. 8). Alternatively, asymmetry in rift structure may not be due to post-ca. 45 Ma magmatism, but rather may have been caused by Paleozoic structural inheritance proposed to have exerted a major control on the location of the Main Ethiopian Rift (Bastow et al., 2008, Keranen and Klemperer, 2008; Keranen et al., 2009; Agostini et al., 2009; Cornwell et al., 2010). However, such a hypothesis is hard to test because of the paucity of basement fabrics exposed in Ethiopia (e.g., Church, 1991).

\section{Ethiopian Lithospheric Structure}

Despite the abundance of geophysical information available for Ethiopia's upper mantle (Debayle et al., 2001; Bastow et al., 2005, 2008; Benoit et al., 2006a, 2006b; Pasyanos and Nyblade, 
2007; Priestley et al., 2008) and the plethora of aforementioned images of crustal structure, less is known about the deeper lithospheric structure $(45-75 \mathrm{~km})$ because the data/methods employed by EAGLE do not sample the range well. Teleseismic tomography has insufficient crossing rays to resolve this depth range, and it is toward the limits of the depth resolution of the wide-angle seismic profiles and the magnetotelluric survey. This depth range is important, however, because it constrains the link between surface observations of Quaternary volcanism and crustal magma intrusion and deeper sources of melt in the upper mantle that likely link to the underlying African superplume structure. The mantle reflectors identified by Maguire et al. (2006) beneath both controlled-source profiles (Fig. 10) were also noted in earlier wide-angle studies in Ethiopia (Berckhemer et al., 1975; Makris and Ginzburg, 1987) and further south in Kenya (e.g., Maguire et al., 1994). Beneath Afar, the reflector shallows by $\sim 20 \mathrm{~km}$, but it remains $10-25 \mathrm{~km}$ beneath the Moho throughout the study area. Several causes of mantle reflectors in the depth range $50-100 \mathrm{~km}$ depth are discussed by Levin and Park (2000). Maguire et al. (2006), however, believe that the reflector is a compositional or structural boundary within preexisting lithosphere, owing to the correlation of reflector depth with the amount of lithospheric extension, rather than a phase change or melt front.

SKS shear-wave splitting analyses by Kendall et al. (2005) indicate that some parts of Ethiopia are amongst the most anisotropic worldwide ( $\delta t$ up to $\sim 3 \mathrm{~s}$; Fig. 7). A rotation of the fast splitting direction $(\phi)$ within the Main Ethiopian Rift may mirror a shift from $\mathrm{N} 130^{\circ} \mathrm{E}$-directed extension to $\mathrm{N} 110^{\circ} \mathrm{E}$-directed extension at ca. $2 \mathrm{Ma}$, when crustal strain localized toward the Wonji fault belt (Wolfenden et al., 2004). Alternatively, analog modeling of deformation in Ethiopia (Corti, 2008, 2009) shows that the same evolution in structural trends since the mid-Miocene can be obtained by uniformly directed $\mathrm{N} 110^{\circ} \mathrm{E}$ extension of the lithosphere with early border fault structural trends controlled by preexisting lithospheric structural inheritances buried beneath Cenozoic flood basalts. Either way, the SKS results provide compelling evidence to suggest that anisotropy is dominated by rifting processes. It is difficult to discriminate among anisotropy due to olivine lattice preferred orientation (LPO) associated with mantle flow, fossil anisotropy in the lithosphere, and anisotropy due to oriented melt pockets (OMP). Analyses of interstation phase velocities for Love $\left(\mathrm{L}_{\mathrm{Q}}\right)$ and Rayleigh waves $\left(\mathrm{L}_{\mathrm{R}}\right)$ in the Main Ethiopian Rift can be used to distinguish between different mechanisms of anisotropy (Fig. 5; e.g., Bastow et al., 2010). These analyses in Ethiopia (Fig. 6) show that anisotropy in at least the top $\sim 45 \mathrm{~km}$ of the lithosphere beneath the Main Ethiopian Rift is controlled by OMP-type anisotropy (e.g., Kendall et al., 2005). Intriguingly, SKS delay times peak at $\sim 9^{\circ} \mathrm{N}$ (not in Afar), where lowest velocities are thought to exist beneath Ethiopia (e.g., Bastow et al., 2008, 2010). Kendall et al. (2005) also noted that $\delta t$ is higher at the rift flanks than beneath the rift axis. A factor consistent with this is the observed offset of lowest-velocity zones in the upper mantle (Bastow et al., 2005, 2008). This offset of low-velocity anomalies away from the center of the rift toward the uplifted rift flanks (Fig. 4) indicates some linkage between the fault-controlled strain and the development of the upper-mantle along-axis segmentation (Bastow et al., 2008). Such observations show that preexisting, as well as strain (rifting)-induced, baseof-lithosphere topography may play an important role in melt transport beneath the rift system (Bastow et al., 2005, 2008). If the mantle organizes itself as it would beneath a fully developed seafloor spreading center (e.g., Kuo and Forsyth, 1988; PhippsMorgan and Chen, 1993; Gregg et al., 2007; Wang et al., 2009), with low velocities directly beneath Quaternary volcanic centers, it is expected to do so further north into Afar (Fig. 1), where the influence of the steep base-of-lithosphere topography of the Miocene border faults is reduced as the rift progressively widens (Bastow et al., 2008).

\section{CONCLUSIONS AND FOCUS FOR FUTURE RESEARCH}

We have summarized a major geoscientific experiment in East Africa: the Ethiopia Afar Geoscientific Lithospheric Experiment (EAGLE), which probed crust and upper-mantle structure in a region of incipient continental breakup. Seismic tomography reveals some of the lowest-velocity mantle worldwide in a broad ( 500-km-wide) upwelling beneath the Main Ethiopian Rift and uplifted Ethiopian Plateau. This anomalous body likely originated from Paleogene flood basaltic volcanism that presently sits atop the Ethiopian Plateau. We now know that this source of partial melt is playing an integral role in the breakup of the African continent in Ethiopia. Controlled-source seismic profiles, in conjunction with magnetotelluric, gravity, crustal seismic analyses, and geological observations, show that extension in the Main Ethiopian Rift is not accommodated by simple or pure shear of the lithosphere, but by a magma-assisted rifting model in which gabbroic intrusions (dikes and veins) achieve extension without marked crustal thinning. The observations from Ethiopia join a growing body of evidence from continental rifts (e.g., Thybo and Nielsen, 2009) and passive margins (e.g., White et al., 2008) that show that magma intrusion plays an important role in accommodating extension during continental breakup. A summary of the major findings and ideas we have discussed is shown in Figure 13. EAGLE has addressed many of the fundamental first-order questions about the transition from continental rifting to incipient oceanic spreading, but many questions remain, and these questions will fuel future generations of research in East Africa:

What are the causes of seismic heterogeneity in the mantle, and how can images of broad mantle upwellings be reconciled with geochemical models of mantle plumes (e.g., Ebinger and Sleep, 1998; George et al., 1998; Pik et al., 1999, 2003; Rogers et al., 2000; Rogers, 2006; Beccaluva et al., 2009; Ayalew and Gibson, 2009)?

At what stage and by what mechanism in the breakup process does the mantle organize itself into punctuated upwellings 


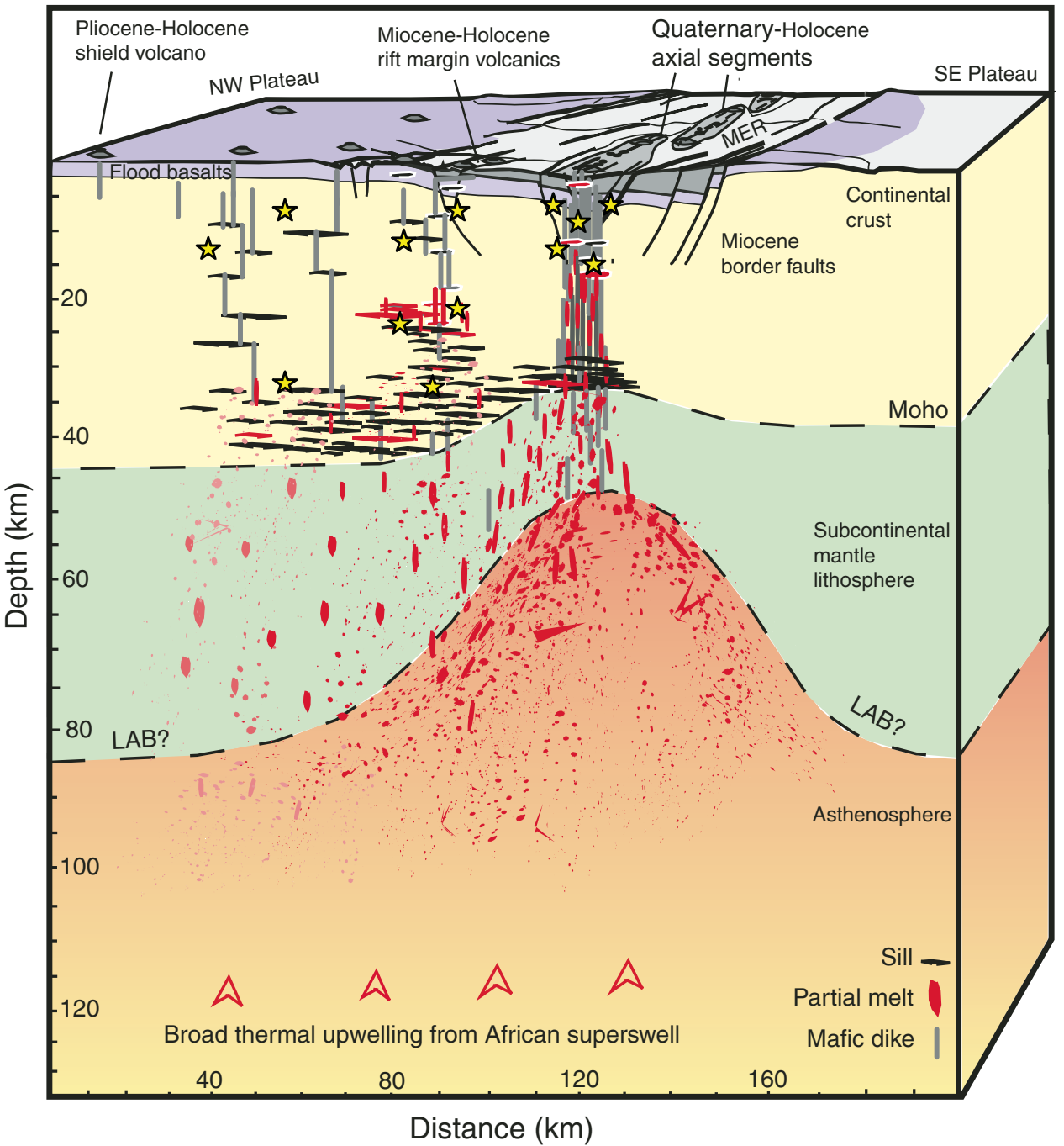

Figure 13. Conceptual model for the Main Ethiopian Rift (MER) based on the results from the Ethiopia Afar Geoscientific Lithospheric Experiment (EAGLE) project and complementary geoscientific studies. During Pliocene times, $2 \mathrm{~km}$ of flood basalts and rhyolites (purple) were erupted onto the Ethiopian Plateau, giving rise to shield volcanoes and underplate beneath the NW plateau. During the Miocene, border faults accommodated extension as rifting of the elevated plateau began. By Quaternary times, the locus of extension had then shifted to the axis of the Main Ethiopian Rift, where magma intrusion accommodated most of the extension without marked crustal thinning. Today, we see evidence of these magmatic processes in the form of magnetotellurically inferred melt zones and associated seismicity throughout the crust. Beneath the Main Ethiopian Rift, some of the lowest mantle velocities on Earth are best explained by a hypothesis of high temperatures and partial melt, which flows in a complex manner in response to the base of lithosphere topography. Deeper still, the low-velocity region is $500 \mathrm{~km}$ wide and likely connects across the transition zone to the deeper African superplume. LAB-lithosphereasthenosphere boundary. as is observed beneath a proto-seafloor spreading center (e.g., Bonatti, 1985; Wang et al., 2009)?

What is the composition and geometry, and over what timescales is melt delivered from the upper mantle to various depths within the crust? How is strain partitioned between ductile stretching, and magma injection in the lithosphere? These questions have fundamental implications for the thermal-mechanical evolution of potential hydrocarbon passive margins and failed rifts (e.g., Thybo et al., 2009).

Does fault growth along the rift axis occur primarily during episodes of increased dike intrusion, such as is currently being observed in the subaerial Red Sea Rift in Afar (e.g., Rowland et al., 2007; Grandin et al., 2009), or does the majority of fault growth occur during amagmatic interdiking periods? Discrimination between these two end-member models has important implications for seismic hazard assessment in Ethiopia, since a model of co-diking fault growth implies that prediction of the repeat times of dike injections is more important than an understanding of a fault-controlled seismic cycle.

\section{ACKNOWLEDGMENTS}

We thank the Ethiopia Afar Geoscientific Lithospheric Experiment (EAGLE) working group for fruitful discussions over the years since EAGLE began. Cindy Ebinger provided invaluable advice that improved the manuscript. Research staff at Addis Ababa University, especially Laike Mariam Asfaw, Bekele Abebe, Atalay Ayele, Dereje Ayalew, Gezahegn Yirgu, and Tesfaye Kidane, are gratefully acknowledged for their considerable scientific insight and invaluable support, without which the EAGLE project would not have been possible. Peter Maguire and Ullrich Achauer provided helpful reviews that improved the quality of the manuscript. IB funded by the Leverhulme Trust. DK funded by National Environment Research Council fellowship NE/E013945/1. 


\section{REFERENCES CITED}

Abdallah, A., Courtillot, V., Kasser, M., Le Dain, A.-Y., Lépine, C., Rabineau, B., Ruegg, J.C., Tapponnier, P., and Trantola, P., 1979, Relevance of Afar seismicity and volcanism to the mechanics of accreting plate boundaries: Nature, v. 282, p. 17-23, doi:10.1038/282017a0.

Abebe, B., Acocella, V., Korme, T., and Ayalew, D., 2007, Quaternary faulting and volcanism in the Main Ethiopian Rift: Journal of African Earth Sciences, v. 48, p. 115-124, doi:10.1016/j.jafrearsci.2006.10.005.

Acocella, V., and Korme, T., 2002, Holocene extension direction along the Main Ethiopian Rift, East Africa: Terra Nova, v. 14, p. 191-197, doi:10.1046/ j.1365-3121.2002.00403.x.

Acocella, V., Korme, T., and Salvini, F., 2003, Formation of normal faults along the axial zone of the Ethiopian Rift: Journal of Structural Geology, v. 25, p. 503-513.

Agostini, A., Corti, G., Zeoli, A., and Mulugeta, G., 2009, Evolution, pattern, and partitioning of deformation during oblique continental rifting: Inferences from lithospheric-scale centrifuge models: Geochemistry, Geophysics, Geosystems, v. 10, no. 11, Q11015, doi:10.1029/2009GC002676.

Asfaw, L., 1982, Development of earthquake-induced fissures in the Main Ethiopian Rift: Nature, v. 297, no. 5865, p.0 393-395, doi:10.1038/297393a0.

Asfaw, L., Bilham, R., Jackson, M., and Mohr, P., 1992, Recent inactivity in African rift: Nature, v. 357, no. 6378, p. 447, doi:10.1038/357447a0.

Ayalew, D., and Gibson, S.A., 2009, Head-to-tail transition of the Afar mantle plume: Geochemical evidence from a Miocene bimodal basalt-rhyolite succession in the Ethiopian large igneous province: Lithos, v. 112, no. 3-4, p. 461-476, doi:10.1016/j.lithos.2009.04.005.

Ayele, A., 2000, Normal left-oblique fault mechanisms as an indication of sinistral deformation between the Nubia and Somalia plates in the Main Ethiopian Rift: Journal of African Earth Sciences, v. 31, no. 2, p. 359-367, doi:10.1016/S0899-5362(00)00093-2.

Ayele, A., and Arvidsson, R., 1997, Fault mechanisms and tectonic implication of the 1985-1987 earthquake sequence in south-western Ethiopia: Journal of Seismology, v. 1, no. 4, p. 383-394, doi:10.1023/A:1009774331917.

Ayele, A., and Kulhánek, O., 1997, Spatial and temporal variation of the seismicity in the Horn of Africa from 1960-1993: Geophysical Journal International, v. 130, p. 805-810, doi:10.1111/j.1365-246X.1997.tb01875.x.

Ayele, A., Stuart, G.W., and Kendall, J.-M., 2004, Insights into rifting from shear wave splitting and receiver functions: An example from Ethiopia: Geophysical Journal International, v. 157, p. 354-362, doi:10.1111/j.1365 $-246 X .2004 .02206 . x$.

Ayele, A., Jacques, E., Kassim, M., Kidane, T., Omar, A., Tait, S., Nercessian, A., de Chabalier, J.-B., and King, G., 2007a, The volcano-seismic crisis in Afar, Ethiopia, starting September 2005: Earth and Planetary Science Letters, v. 48, p. 70-79.

Ayele, A., Stuart, G.W., Bastow, I.D., and Keir, D., 2007b, The August 2002 earthquake sequence in north Afar: Insights into the neotectonics of the Danakil microplate: Journal of African Earth Sciences, v. 48, p. 70-79, doi:10.1016/j.jafrearsci.2006.06.011.

Baker, J., Snee, L., and Menzies, M., 1996, A brief Oligocene period of flood volcanism in Yemen: Earth and Planetary Science Letters, v. 138, p. 39-55, doi:10.1016/0012-821X(95)00229-6.

Barclay, A.H., and Toomey, D.R., 2003, Shear wave splitting and crustal anisotropy at the Mid-Atlantic Ridge, $35^{\circ} \mathrm{N}$ : Journal of Geophysical Research, v. 108, no. B8, p. 2378, doi:10.1029/2001JB000918.

Bastow, I.D., Stuart, G.W., Kendall, J.-M., and Ebinger, C.J., 2005, Uppermantle seismic structure in a region of incipient continental breakup: Northern Ethiopian Rift: Geophysical Journal International, v. 162, p. 479-493, doi:10.1111/j.1365-246X.2005.02666.x.

Bastow, I.D., Owens, T.J., Helffrich, G., and Knapp, J.H., 2007, Spatial and temporal constraints on sources of seismic anisotropy: Evidence from the Scottish Highlands: Geophysical Research Letters, v. 34, no. 5, doi:10.1029/2006GL028911.

Bastow, I.D., Nyblade, A.A., Stuart, G.W., Rooney, T.O., and Benoit, M.H., 2008, Upper mantle seismic structure beneath the Ethiopian hotspot: Rifting at the edge of the African low velocity anomaly: Geochemistry, Geophysics, Geosystems, v. 9, Q12022, doi:10.1029/2008GC002107.

Bastow, I.D., Pilidou, S., Kendall, J.-M., and Stuart, G.W., 2010, Melt-induced seismic anisotropy and magma assisted rifting in Ethiopia: Evidence from surface waves: Geochemistry, Geophysics, Geosystems, v. 11, Q0AB05, doi:10.1029/2010GC003036.
Beccaluva, L., Bianchini, G., Natali, C., and Siena, F., 2009, Continental flood basalts and mantle plumes: A case study of the northern Ethiopian Plateau: Journal of Petrology, v. 50, p. 1377-1403, doi:10.1093/petrology/egp024.

Bellahsen, N., Faccenna, C., Funiciello, F., Daniel, J.M., and Jolivet, L., 2003, Why did Arabia separate from Africa? Insights from 3-D laboratory experiments: Earth and Planetary Science Letters, v. 216, no. 3, p. 365381, doi:10.1016/S0012-821X(03)00516-8.

Bendick, R., McClusky, S., Bilham, R., Asfaw, L., and Klemperer, S., 2006, Distributed Nubia-Somalia relative motion and dike intrusion in the Main Ethiopian Rift: Geophysical Journal International, v. 165, p. 303-310, doi:10.1111/j.1365-246X.2006.02904.x.

Benoit, M.H., Nyblade, A.A., Owens, T.J., and Stuart, G.W., 2006a, Mantle transition zone structure and upper mantle $\mathrm{S}$ velocity variations beneath Ethiopia: Evidence for a broad, deep-seated thermal anomaly: Geochemistry, Geophysics, Geosystems, v. 7, Q11013, doi:10.1029/2006GC001398.

Benoit, M.H., Nyblade, A.A., and VanDecar, J.C., 2006b, Upper mantle P wavespeed variations beneath Ethiopia and the origin of the Afar hotspot: Geology, v. 34, no. 5, p. 329-332, doi:10.1130/G22281.1.

Berckhemer, H., Baier, B., Bartlesen, H., Behle, A., Burkhardt, H., Gebrande, H., Makris, J., Menzel, H., Miller, H., and Vees, R., 1975, Deep seismic soundings in the Afar region and on the highland of Ethiopia, in Pilger, A., and Rösler, A., eds., Afar Depression of Ethiopia: Stuttgart, Schweizerbart, p. 89-107.

Berhe, S.M., 1990, Ophiolites in northeast and East Africa: Implications for Proterozoic crustal growth: Journal of the Geological Society of London, v. 147, p. 41-57, doi:10.1144/gsigs.147.1.0041.

Beutel, E., van Wijk, J., Ebinger, C., Keir, D., and Agostini, A., 2010, Formation and stability of magmatic segments in the Main Ethiopian and Afar Rifts: Earth and Planetary Science Letters, v. 293, p. 225-235, doi:10.1016/j .epsl.2010.02.006.

Bilham, R., Bendick, R., Larson, K., Mohr, P., Braun, J., Tesfaye, S., and Asfaw, L., 1999, Secular and tidal strain across the Main Ethiopian Rift: Geophysical Research Letters, v. 26, p. 2789-2792, doi:10.1029/1998GL005315.

Björnsson, A., Saemundsson, K., Einarsson, P., Tryggvason, E., and Grönvold, K., 1977, Current rifting episode in north Iceland: Nature, v. 266, no. 5600, p. 318-323, doi:10.1038/266318a0.

Boccaletti, M., Bonini, M., Mazzuoli, R., Abebe, B., Piccardi, L., and Tortorici, L., 1998, Quaternary oblique extensional tectonics in the Ethiopian Rift (Horn of Africa): Tectonophysics, v. 287, no. 1-4, p. 97-116, doi:10.1016/ S0040-1951(98)80063-2.

Bonatti, E., 1985, Punctiform initiation of seafloor spreading in the Red Sea during transition from a continental to an oceanic rift: Nature, v. 316, no. 6023 , p. 33-37, doi: $10.1038 / 316033 \mathrm{a} 0$

Bonini, M., Souriot, T., Boccaletti, M., and Brun, J., 1997, Successive orthogonal and oblique extension episodes in a rift zone: Laboratory experiments with application to the Ethiopian Rift: Tectonics, v. 16, no. 2, p. 347-362, doi:10.1029/96TC03935.

Bonini, M., Corti, G., Innocenti, F., Manetti, P., and Mazzarini, F., 2005, Evolution of the Main Ethiopian Rift in the frame of Afar and Kenya Rift propagation: Tectonics, v. 24, no. 1, TC1007, doi:10.1029/2004TC001680.

Bown, J.W., and White, R.S., 1995, Effect of finite extension rate on melt generation at rifted continental margins: Journal of Geophysical Research, v. 100, no. B9, p. 18,011-18,029, doi:10.1029/94JB01478.

Brazier, R.A., Miao, Q., Nyblade, A.A., Ayele, A., and Langston, C.A., 2008 , Local magnitude scale for the Ethiopian Plateau: Bulletin of the Seismological Society of America, v. 98, no. 5, p. 2341, doi:10.1785/0120070266.

Brown, G.F., 1970, Eastern margin of Red Sea and coastal structures in Saudi Arabia: Philosophical Transactions of the Royal Society of London, v. 267, p. 75-87.

Buck, W.R., 1991, Modes of continental lithospheric extension: Pure and simple: Journal of Geophysical Research, v. 96, no. B12, p. 20,161-20,178, doi:10.1029/91JB01485.

Buck, W.R., 2004, Consequences of asthenospheric variability on continental rifting, in Karner, G., Taylor, B., Driscoll, N.W., and Kohlstedt, D.L., eds., Rheology and Deformation of the Lithosphere at Continental Margins: New York, Columbia University Press, p. 1-30.

Buck, W.R., 2006, The role of magma in the development of the Afro-Arabian rift system, in Yirgu, G., Ebinger, C.J., and Maguire, P.K.H., eds., The Afar Volcanic Province within the East African Rift System: Geological Society of London Special Publication 259, p. 43-54.

Calais, E., Ebinger, C., Hartnady, C., and Nocquet, J., 2006, Kinematics of the East African Rift from GPS and earthquake slip vector data, in Yirgu, G., Ebinger, C.J., and Maguire, P.K.H., eds., The Afar Volcanic Province 
within the East African Rift System: Geological Society of London Special Publication 259, p. 9-23.

Casey, M., Ebinger, C., Keir, D., Gloaguen, R., and Mohammed, F., 2006, Strain accommodation in transitional rifts: Extension by magma intrusion and faulting, in Yirgu, G., Ebinger, C.J., and Maguire, P.K.H., eds., The Afar Volcanic Province within the East African Rift System: Geological Society of London Special Publication 259, p. 143-163.

Chernet, T., Hart, W.K., Aronson, I.L., and Walter, R.C., 1998, New age constraints on the timing of volcanism and tectonism in the northern Main Ethiopian Rift-Southern Afar transition zone (Ethiopia): Journal of Volcanology and Geothermal Research, v. 80, p. 267-280, doi:10.1016/ S0377-0273(97)00035-8.

Chevrot, S., and van der Hilst, R.D., 2000, The Poisson's ratio of the Australian crust: Geological and geophysical implications: Earth and Planetary Science Letters, v. 183, p. 121-132, doi:10.1016/S0012-821X(00)00264-8.

Christensen, N.I., 1996, Poisson's ratio and crustal seismology: Journal of Geophysical Research, v. 101, no. B2, p. 3139-3156, doi:10.1029/95JB03446.

Church, W.R., 1991, Discussion of "Ophiolites in northeast and East Africa: Implications for Proterozoic crustal growth": Journal of the Geological Society of London, v. 48, p. 600-606.

Coffin, M.F., and Eldholm, O., 1994, Large igneous provinces: Crustal structure, dimensions, and external consequences: Reviews of Geophysics, v. 32, no. 1, p. 1-36, doi:10.1029/93RG02508.

Cornwell, D., Mackenzie, G., England, R., Maguire, P., Asfaw, L., and Oluma, B., 2006, Northern Main Ethiopian Rift crustal structure from new highprecision gravity data, in Yirgu, G., Ebinger, C.J., and Maguire, P.K.H., eds., The Afar Volcanic Province within the East African Rift System: Geological Society of London Special Publication 259, p. 307-321.

Cornwell, D.G., Maguire, P.K.H., England, R.W., and Stuart, G.W., 2010 , Imaging detailed crustal structure and magmatic intrusion across the Ethiopian Rift using a dense linear broadband array: Geochemistry, Geophysics, Geosystems, v. 11, Q0AB03, doi:10.1029/2009GC002637.

Corti, G., 2008, Control of rift obliquity on the evolution and segmentation of the main Ethiopian Rift: Nature Geoscience, v. 1, no. 4, p. 258-262, doi:10.1038/ngeo160.

Corti, G., 2009, Continental rift evolution: From rift initiation to incipient break-up in the Main Ethiopian Rift, East Africa: Earth-Science Reviews, v. 96, p. 1-53, doi:10.1016/j.earscirev.2009.06.005.

Crampin, S., Gao, Y., and Peacock, S., 2008, Stress-forecasting (not predicting) earthquakes: A paradigm shift?: Geology, v. 36, no. 5, p. 427-430, doi:10.1130/G24643A.1.

d'Acremont, E., Leroy, S., Beslier, M.O., Bellahsen, N., Fournier, M., Robin, C., Maia, M., and Gente, P., 2005, Structure and evolution of the eastern Gulf of Aden conjugate margins from seismic reflection data: Geophysical Journal International, v. 160, no. 3, p. 869-890, doi:10.1111/j.1365 -246X.2005.02524.x.

Daly, E., Keir, D., Ebinger, C.J., Stuart, G.W., Bastow, I.D., and Ayele, A., 2008 , Crustal tomographic imaging of a transitional continental rift: The Ethiopian Rift: Geophysical Journal International, v. 172, no. 3, p. 1033-1048, doi:10.1111/j.1365-246X.2007.03682.x.

Debayle, E., Lévêque, J.J., and Cara, M., 2001, Seismic evidence for a deeply rooted low-velocity anomaly in the upper mantle beneath the northeastern Afro/Arabian continent: Earth and Planetary Science Letters, v. 193, p. 423-436, doi:10.1016/S0012-821X(01)00509-X.

De Chabalier, J.B., and Avouac, J.P., 1994, Kinematics of the Asal Rift, Djibouti, determined from the deformation of the Fieale volcano: Science, v. 265, p. 1677-1681, doi:10.1126/science.265.5179.1677.

Di Leo, J., Bastow, I.D., and Helffrich, G., 2009, Nature of the Moho beneath the Scottish Highlands from a receiver function perspective: Tectonophysics, doi:10.1016/j.tecto.2009.08.014.

Dugda, M.T., Nyblade, A.A., Julià, J., Langston, C.A., Ammon, C.A., and Simiyu, S., 2005, Crustal structure in Ethiopia and Kenya from receiver function analysis: Journal of Geophysical Research, v. 110, no. B1, doi:10.1029/2004JB003065.

Duggen, S., Hoernle, K., and van den Bogaard, P.R., 2003, Deep roots of the Messinian salinity crisis: Nature, v. 422, p. 602-606, doi:10.1038/nature01553.

Ebinger, C.J., 2005, Continental break-up: The East African perspective: Astronomy \& Geophysics, v. 46, p. 16-21, doi:10.1111/j.1468-4004 .2005.46216.x.

Ebinger, C.J., and Casey, M., 2001, Continental breakup in magmatic provinces: An Ethiopian example: Geology, v. 29, p. 527-530, doi:10.1130/0091-7613 (2001) $029<0527:$ CBIMPA $>2.0$. CO;2.
Ebinger, C., and Hayward, N., 1996, Soft plates and hot spots: Views from Afar: Journal of Geophysical Research, v. 101, no. B10, p. 21,859-21,876, doi:10.1029/96JB02118.

Ebinger, C., and Sleep, N., 1998, Cenozoic magmatism throughout East Africa resulting from impact of a single plume: Nature, v. 395, p. 788-791, doi: $10.1038 / 27417$.

Ebinger, C.J., Yemane, T., WoldeGabriel, G., Aronson, J., and Walter, R., 1993, Eocene-Recent volcanism and faulting in the southern Main Ethiopian Rift: Journal of the Geological Society of London, v. 150, p. 99-108, doi:10.1144/gsjgs.150.1.0099.

Ebinger, C.J., Jackson, J.A., Foster, A.N., and Hayward, N.J., 1999, Extensional basin geometry and the elastic lithosphere: Philosophical Transactions of the Royal Society of London, ser. A, Mathematical Physical and Engineering Sciences, v. 150, p. 99-108.

Ebinger, C.J., Yemane, T., Harding, T.J., Tesfaye, S., Kelley, S., and Rex, D.C., 2000, Rift deflection, migration, and propagation: Linkage of the Ethiopian and Eastern Rifts, Africa: Geological Society of America Bulletin, v. 112, no. 2, p. 163-176, doi:10.1130/0016-7606(2000)112<163: RDMAPL $>2.0 . \mathrm{CO} ; 2$

Ebinger, C., Ayele, A., Keir, D., Rowland, J., Yirgu, G., Wright, T., Belachew, M., and Hamling, I., 2010, Length and timescales of rift faulting and magma intrusion: The Afar rifting cycle from 2005 to present: Annual Review of Earth and Planetary Sciences, v. 38, p. 439-466, doi:10.1146/ annurev-earth-040809-152333.

Evans, J.R., and Achauer, U., 1993, Teleseismic tomography using the $\mathrm{ACH}$ method: Theory and application to continental scale studies, in Iyer, H., and Hirahara, K., eds., Seismic Tomography: Theory and Practice: New York, Chapman and Hall, p. 319-360.

Fernandes, R.M.S., Ambrousius, B.A.C., Noomen, R., Bastos, L., Combrinck, L., Miranda, J.M., and Spakman, W., 2004, Angular velocities of Nubia and Somalia from continuous GPS data: Implications on present-day relative kinematics: Earth and Planetary Science Letters, v. 222, p. 197-208, doi:10.1016/j.eps1.2004.02.008.

Foster, A., and Jackson, J., 1998, Source parameters of large African earthquakes: Implications for crustal rheology and regional kinematics: Geophysical Journal International, v. 134, p. 422-448, doi:10.1046/j.1365 $-246 x .1998 .00568 . x$.

Furman, T., Bryce, J., Hanan, B., Yirgu, G., and Ayalew, D., 2006, Heads and tails: 30 years of the Afar plume, in Yirgu, G., Ebinger, C.J., and Maguire, P.K.H., eds., The Afar Volcanic Province within the East African Rift System: Geological Society of London Special Publication 259, p. 95-119.

Gani, N.D.S., Gani, M.R., and Abdelsalam, M.G., 2007, Blue Nile incision on the Ethiopian Plateau: Pulsed plateau growth, Pliocene uplift, and hominin evolution: GSA Today, v. 17, no. 9, p. 4-11, doi:10.1130/GSAT01709A.1.

Gashawbeza, E.M., Klemperer, S.L., Nyblade, A.A., Walker, K.T., and Keranen, K.M., 2004, Shear-wave splitting in Ethiopia: Precambrian mantle anisotropy locally modified by Neogene rifting: Geophysical Research Letters, v. 31, doi:10.1029/2004GL020471.

George, R., Rogers, N., and Kelley, S., 1998, Earliest magmatism in Ethiopia: Evidence for two mantle plumes in one continental flood basalt province: Geology, v. 26, p. 923-926, doi:10.1130/0091-7613(1998)026<0923: EMIEEF $>2.3 . \mathrm{CO} ; 2$.

Gibson, I., 1969, The structure and volcanic geology of an axial portion of the Main Ethiopian Rift: Tectonophysics, v. 8, p. 561-565, doi:10.1016/0040 -1951(69)90054-7.

Gouin, P., 1979, Earthquake History of Ethiopia and the Horn of Africa: Ottawa, Ontario, International Development Research Centre (IDRC), 258 p.

Grand, S.P., 2002, Mantle shear-wave tomography and the fate of subducted slabs: Royal Society of London Philosophical Transactions, ser. A, v. 360, p. 2475-2491, doi:10.1098/rsta.2002.1077.

Grandin, R., Socquet, A., Binet, R., Klinger, Y., Jacques, E., De Chabalier, J.-B., King, G.C.P., Lasserre, C., Tait, S., Tapponnier, P., Delorme, A., and Pinzuti, P., 2009, 2005 Manda Hararo-Dabbahu rifting event, Afar (Ethiopia): Constraints provided by geodetic data: Journal of Geophysical Research, v. 114, B08404, doi:10.1029/2008JB005843.

Gregg, P.M., Lin, J., Behn, M.D., and Montesi, L.G.I., 2007, Spreading rate dependence of gravity anomalies along oceanic transform faults: Nature, v. 448, doi:10.1038/nature 05962

Gregory, J., 1896, The Great Rift Valley: Being the Narrative of a Journey to Mount Kenya and Lake Baringo: With Some Account of the Geology, Natural History, Anthropology and Future Prospects of British East Africa: London, J. Murray, 423 p. 
Hamling, I., Ayele, A., Bennati, L., Calais, E., Ebinger, C., Keir, D., Lewi, E., Wright, T., and Yirgu, G., 2009, Geodetic observations of the ongoing Dabbahu rifting episode: New dyke intrusions in 2006 and 2007: Geophysical Journal International, v. 178, p. 989-1003, doi:10.1111/j.1365 -246X.2009.04163.x.

Hayward, N.J., and Ebinger, C.J., 1996, Variations in the along-axis segmentation of the Afar Rift system: Tectonics, v. 15, p. 244-257, doi:10.1029/95TC02292.

Hendrie, D.B., Kusznir, N.J., Morley, C.K., and Ebinger, C.J., 1994, Cenozoic extension in northern Kenya: A quantitative model of rift basin development in the Turkana region: Tectonophysics, v. 236, no. 1-4, p. 409-438, doi:10.1016/0040-1951(94)90187-2.

Hofmann, C., Courtillot, V., Feraud, G., Rochette, P., Yirgu, G., Ketefo, E., and Pik, R., 1997, Timing of the Ethiopian flood basalt event and implications for plume birth and global change: Nature, v. 389 , p. 838-841, doi:10.1038/39853.

Hofstetter, R., and Beyth, M., 2003, The Afar Depression: Interpretation of the 1960-2000 earthquakes: Geophysical Journal International, v. 155, no. 2, p. 715-732, doi:10.1046/j.1365-246X.2003.02080.x.

Holbrook, W., and Kelemen, P., 1993, Large igneous province on the US Atlantic margin and implications for magmatism during breakup: Nature, v. 364, p. 433-436, doi:10.1038/364433a0.

Hopper, J., and Buck, W.R., 1993, The initiation of rifting at constant tectonic force: The role of diffusion creep: Journal of Geophysical Research, v. 98, p. 16,213-16,221, doi:10.1029/93JB01725.

Kazmin, V., Shifferaw, A., and Balcha, T., 1978, The Ethiopian basement: Stratigraphy and possible manner of evolution: International Journal of Earth Sciences, v. 67, p. 531-546.

Kebede, F., and Kulhánek, O., 1994, Spatial and temporal variations of b-values along the East African Rift system and the southern Red Sea: Physics of the Earth and Planetary Interiors, v. 83, p. 249-264, doi:10.1016/0031 -9201(94)90092-2.

Kebede, F., and van Eck, T., 1997, Probabilistic seismic hazard assessment for the Horn of Africa based on seismotectonic regionalization: Tectonophysics, v. 270, p. 221-237, doi:10.1016/S0040-1951(96)00215-6.

Keir, D., Kendall, J.-M., Ebinger, C.J., and Stuart, G.W., 2005, Variations in late syn-rift melt alignment inferred from shear-wave splitting in crustal earthquakes beneath the Ethiopian Rift: Geophysical Research Letters, v. 32, L23308, doi:10.1029/2005GL024150.

Keir, D., Stuart, G.W., Jackson, A., and Ayele, A., 2006a, Local earthquake magnitude scale and seismicity rate of the northern Ethiopian Rift: Bulletin of the Seismological Society of America, v. 96, doi:10.1785/0120060051.

Keir, D., Ebinger, C.J., Stuart, G.W., Daly E., and Ayele, A., 2006b, Strain accommodation by magmatism and faulting as rifting proceeds to breakup: Seismicity of the northern Ethiopian Rift: Journal of Geophysical Research, v. 111, B05314, doi:10.1029/2005JB003748.

Keir, D., Hamling, I.J., Ayele, A., Calais, E., Ebinger, C., Wright, T.J., Jacques, E., Mohamed, K., Hammond, J.O.S., Belachew, M., Baker, E., Rowland, J.V., Lewi, E., and Bennati, L., 2009a, Evidence for focused magmatic accretion at segment centers from lateral dike injections captured beneath the Red Sea Rift in Afar: Geology, v. 37, p. 59-62, doi:10.1130/G25147A.1

Keir, D., Bastow, I.D., Whaler, K.A., Daly, E., Cornwell, D.G., and Hautot, S., 2009b, Lower crustal earthquakes near the Ethiopian Rift induced by magmatic processes: Geochemistry, Geophysics, Geosystems, v. 10, p. 1-10, doi:10.1029/2009GC002382.

Kendall, J.-M., 2000, Seismic anisotropy in the boundary layers of the mantle, in Karato, S., Stixrude, L., Liebermann, R.C., and Masters, T.G., eds., Earth's Deep Interior; Mineral Physics and Tomography from the Atomic to the Global Scale: Washington, D.C., American Geophysical Union Geophysical Monograph 117, p. 149-175.

Kendall, J.-M., Stuart, G.W., Ebinger, C.J., Bastow, I.D., and Keir, D., 2005, Magma assisted rifting in Ethiopia: Nature, v. 433, p. 146-148, doi:10.1038/nature03161.

Kendall, J.-M., Pilidou, S., Keir, D., Bastow, I., Stuart, G., and Ayele, A., 2006, Mantle upwellings, melt migration and the rifting of Africa: Insights from seismic anisotropy, in Yirgu, G., Ebinger, C.J., and Maguire, P.K.H., eds., The Afar Volcanic Province within the East African Rift System: Geological Society of London Special Publication 259, p. 55-72.

Keranen, K., and Klemperer, S.L., 2008, Discontinuous and diachronous evolution of the Main Ethiopian Rift: Implications for development of continental rifts: Earth and Planetary Science Letters, v. 265, p. 96-111, doi:10.1016/j.eps1.2007.09.038.
Keranen, K., Klemperer, S.L., Gloaguen, R., and EAGLE Working Group, 2004, Three-dimensional seismic imaging of a protoridge axis in the Main Ethiopian Rift: Geology, v. 32, p. 949-952, doi:10.1130/G20737.1.

Keranen, K., Klemperer, S., Julia, J., Lawrence, J., and Nyblade, A., 2009, Low lower-crustal velocity across Ethiopia: Is the Main Ethiopian Rift a narrow rift in a hot craton?: Geochemistry, Geophysics, Geosystems, v. 10, Q0AB01, doi:10.1029/2008GC002293.

Kidane, T., Otofuji, Y.I., Komatsu, Y., Shibasaki, H., and Rowland, J., 2009, Paleomagnetism of the Fentale magmatic segment, Main Ethiopian Rift: New evidence for counterclockwise block rotation linked to transtensional deformation: Physics of the Earth and Planetary Interiors, v. 176, no. 1-2, p. 109-123, doi:10.1016/j.pepi.2009.04.006.

Kieffer, B., Arndt, N., Lapierre, H., Bastien, F., Bosch, D., Pecher, A., Yirgu, G., Ayalew, D., Weiss, D., Jerram, D.A., Keller, F., and Meugniot, C., 2004, Flood and shield basalts from Ethiopia: Magmas from the African superswell: Journal of Petrology, v. 45, no. 4, p. 793-834, doi:10.1093/ petrology/egg112.

Kirkwood, S.C., and Crampin, S., 1981, Surface wave propagation in an ocean basin with an anisotropic upper mantle: Numerical modelling: Geophysical Journal International, v. 64, no. 2, p. 463-485, doi:10.1111/j.1365 -246X.1981.tb02677.x.

Kuo, B.Y., and Forsyth, D.W., 1988, Gravity anomalies of the ridge-transform system in the South Atlantic between 31 and $34.5^{\circ} \mathrm{S}$ : Upwelling centers and variations in crustal thickness: Marine Geophysical Researches, v. 10, no. 3, p. 205-232, doi:10.1007/BF00310065.

Kurz, T., Gloaguen, R., Ebinger, C., Casey, M., and Abebe, B., 2007, Deformation distribution and type in the Main Ethiopian Rift (MER): A remote sensing study: Journal of African Earth Sciences, v. 48, no. 2-3, p. 100 114, doi:10.1016/j.jafrearsci.2006.10.008.

Langston, C.A., 1979, Structure under Mount Rainer, Washington, inferred from teleseismic body waves: Journal of Geophysical Research, v. 84, p. 4749-4762, doi:10.1029/JB084iB09p04749.

Levin, V., and Park, J., 2000, Shear zones in the Proterozoic lithosphere of the Arabian Shield and the nature of the Hales discontinuity: Tectonophysics, v. 323, no. 3-4, p. 131-148, doi:10.1016/S0040-1951(00)00105-0.

Li, C., van der Hilst, R.D., Engdahl, R., and Burdick, S., 2008, A new global model for P wave speed variations in Earth's mantle: Geochemistry, Geophysics, Geosystems, v. 9, no. 5, p. 21, doi:10.1029/2007GC001806.

Long, M.D., and Silver, P.G., 2009, Shear wave splitting and mantle anisotropy: Measurements, interpretations, and new directions: Surveys in Geophysics, v. 30, no. 4, p. 407-461, doi:10.1007/s10712-009-9075-1.

Mackenzie, G.D., Thybo, H., and Maguire, P.K.H., 2005, Crustal velocity structure across the Main Ethiopian Rift: Results from 2-dimensional wide-angle seismic modeling: Geophysical Journal International, v. 162, p. 994-1006, doi:10.1111/j.1365-246X.2005.02710.x.

Maguire, P.K.H., Swain, C.J., Masotti, R., and Khan, M.A., 1994, A crustal and uppermost mantle cross-sectional model of the Kenya rift derived from seismic and gravity data: Tectonophysics, v. 236, p. 217-249, doi:10.1016/0040-1951(94)90178-3.

Maguire, P.K.H., Ebinger, C.J., Stuart, G.W., Mackenzie, G.D., Whaler, K.A., Kendall, J.-M., Khan, M.A., Fowler, C.M.R., Klemperer, S.L., Keller, G.R., Harder, S., Furman, T., Mickus, K., Asfaw, L., Ayele, A., and Abebe, B., 2003, Geophysics project in Ethiopia studies continental breakup: Eos (Transactions, American Geophysical Union), v. 84, no. 35, p. 342-343, doi:10.1029/2003EO350002.

Maguire, P., Keller, G., Klemperer, S., Mackenzie, G., Harder, S., O'Reilly, B.H.T. Asfaw, L., Khan, M., and Amha, M., 2006, Crustal structure of the northern Main Ethiopian Rift from the EAGLE controlled-source survey; a snapshot of incipient lithospheric break-up, in Yirgu, G., Ebinger, C.J., and Maguire, P.K.H., eds., The Afar Volcanic Province within the East African Rift System: Geological Society of London Special Publication 259, p. 269-291.

Mahatsente, R., Jentzsch, G., and Jahr, T., 1999, Crustal structure of the Main Ethiopian Rift from gravity data: 3-dimensional modeling: Tectonophysics, v. 313, p. 363-382, doi:10.1016/S0040-1951(99)00213-9.

Makris, J., and Ginzburg, A., 1987, The Afar Depression: Transition between continental rifting and sea floor spreading: Tectonophysics, v. 141, p. 199-214, doi:10.1016/0040-1951(87)90186-7.

McKenzie, D., 1978, Some remarks on the development of sedimentary basins: Earth and Planetary Science Letters, v. 40, p. 25-32, doi:10.1016/0012 -821X(78)90071-7.

McKenzie, D.P., and Davies, D., 1970, Plate tectonics of the Red Sea and East Africa: Nature, v. 226, p. 243-248, doi:10.1038/226243a0. 
McKenzie, D.P., and Morgan, W.J., 1969, Evolution of triple junctions: Nature, v. 224, p. $125-133$.

Menzies, M., Klemperer, S., Ebinger, C., and Baker, J., 2002, Characteristics of volcanic rifted margins, in Menzies, M., Klemperer, S., Ebinger, C., and Baker, J., eds., Volcanic Rifted Margins: Geological Society of America Special Paper 362, p. 1-14.

Mickus, K., Tadesse, K., Keller, G., and Oluma, B., 2007, Gravity analysis of the Main Ethiopian Rift: Journal of African Earth Sciences, v. 48, no. 2-3, p. 59-69, doi:10.1016/j.jafrearsci.2007.02.008.

Mohr, P.A., 1967, Major volcano-tectonic lineament in the Ethiopian Rift system: Nature, v. 213, p. 664-665, doi:10.1038/213664a0.

Molnar, P., England, P., and Martinod, J., 1993, Mantle dynamics, uplift of the Tibetan Plateau, and the Indian monsoon: Reviews of Geophysics, v. 31, p. 357-396, doi:10.1029/93RG02030.

Montelli, R., Nolet, G., Dahlen, F.A., Masters, G., Engdahl, E.R., and Hung, S.-H., 2004, Finite-frequency tomography reveals a variety of plumes in the mantle: Science, v. 303, p. 338-343, doi:10.1126/science.1092485.

Montelli, R., Nolet, G., Dahlen, F.A., and Masters, G., 2006, A catalogue of deep mantle plumes: New results from finite-frequency tomography: Geochemistry, Geophysics, Geosystems, v. 7, Q11007, doi:10 $.1029 / 2006$ GC001248.

Mutter, J., 1985, Seaward dipping reflectors and the continent-ocean boundary at passive continental margins: Tectonophysics, v. 114, no. 1-4, p. 117131, doi:10.1016/0040-1951(85)90009-5.

Mutter, J., Talwani, M., and Stoffa, P., 1982, Origin of seaward-dipping reflectors in oceanic crust off the Norwegian margin by "subaerial seafloor spreading": Geology, v. 10, no. 7, p. 353-357, doi:10.1130/0091 $-7613(1982) 10<353$ :OOSRIO $>2.0 . C O ; 2$.

Ni, S., Tan, E., Gurnis, M., and Helmberger, D., 2002, Sharp sides to the African superplume: Science, v. 296, p. 1850-1852, doi:10.1126/science.1070698.

Nyblade, A., and Langston, C., 2002, Broadband seismic experiments probe the East African Rift: Eos (Transactions, American Geophysical Union), v. 83, p. 405-410, doi: $10.1029 / 2002$ EO000296.

Nyblade, A.A., Birt, C., Langston, C.A., Owens, T.J., and Last, R.J., 1996, Seismic experiment reveals rifting of craton in Tanzania: Eos (Transactions, American Geophysical Union), v. 77, p. 517, doi:10.1029/96EO00339.

Pasyanos, M.E., and Nyblade, A.A., 2007, A top to bottom lithospheric study of Africa and Arabia: Tectonophysics, v. 444, no. 1-4, p. 27-44, doi:10.1016/j.tecto.2007.07.008.

Peccerillo, A., Barberio, M.R., Yirgu, G., Ayalew, D., Barbieri, M., and Wu, T.W., 2003, Relationships between mafic and peralkaline silicic magmatism in continental rift settings: A petrological, geochemical and isotopic study of the Gedemsa volcano, central Ethiopian Rift: Journal of Petrology, v. 44, no. 11, p. 2003-2032, doi:10.1093/petrology/egg068.

Pérez-Gussinyé, M., Metois, M., Fernández, M., Vergés, J., Fullea, J., and Lowry, A.R., 2009, Effective elastic thickness of Africa and its relationship to other proxies for lithospheric structure and surface tectonics: Earth and Planetary Science Letters, v. 287, no. 1-2, p. 152-167, doi:10.1016/j.epsl.2009.08.004.

Phipps-Morgan, J., and Chen, J., 1993, Dependence of ridge-axis morphology on magma supply and spreading rate: Nature, v. 364, p. 706-708, doi:10.1038/364706a0.

Pik, R., Deniel, C., Coulon, C., Yirgu, G., and Marty, B., 1999, Isotopic and trace element signatures of Ethiopian flood basalts: Evidence for plumelithosphere interactions: Geochimica et Cosmochimica Acta, v. 63, no. 15, p. 2263-2279, doi:10.1016/S0016-7037(99)00141-6.

Pik, R., Marty, B., Carignan, J., and Lavé, J., 2003, Stability of the Upper Nile drainage network (Ethiopia) deduced from (U-Th)/He thermochronometry: Implications for uplift and erosion of the Afar plume dome: Earth and Planetary Science Letters, v. 215, p. 73-88, doi:10.1016/S0012 $-821 \mathrm{X}(03) 00457-6$.

Poupinet, G., 1979, On the relation between P-wave travel time residuals and the age of the continental plates: Earth and Planetary Science Letters, v. 43, p. 149-161, doi:10.1016/0012-821X(79)90163-8.

Priestley, K., McKenzie, D., Debayle, E., and Pilidou, S., 2008, The African upper mantle and its relationship to tectonics and surface geology: Geophysical Journal International, v. 175, no. 3, p. 1108-1126, doi:10.1111/ j.1365-246X.2008.03951.x.

Purcell, P.G., 1976, The Marda fault zone, Ethiopia: Nature, v. 261, p. 569-571, doi:10.1038/261569a0.

Ritsema, J., and Allen, R.M., 2003, The elusive mantle plume: Earth and Planetary Science Letters, v. 207, p. 1-12, doi:10.1016/S0012 $-821 \mathrm{X}(02) 01093-2$.
Ritsema, J., and van Heijst, H., 2000, New seismic model of the upper mantle beneath Africa: Geology, v. 28, no. 1, p. 63-66, doi:10.1130/0091 $-7613(2000) 28<63$ :NSMOTU>2.0.CO;2.

Rogers, N., 2006, Basaltic magmatism and the geodynamics of the East African Rift system, in Yirgu, G., Ebinger, C.J., and Maguire, P.K.H., eds., The Afar Volcanic Province within the East African Rift System: Geological Society of London Special Publication 259, p. 77-93.

Rogers, N., Macdonald, R., Fitton, J.G., George, R., Smith, R., and Barreiro, B., 2000, Two mantle plumes beneath the East African Rift system: Sr, Nd and $\mathrm{Pb}$ isotope evidence from Kenya rift basalts: Earth and Planetary Science Letters, v. 176, p. 387-400, doi:10.1016/S0012-821X(00)00012-1.

Ronga, F., Lustrino, M., Marzoli, A., and Melluso, L., 2010, Petrogenesis of a basalt-comendite-pantellerite rock suite: The Boseti volcanic complex (Main Ethiopian Rift): Mineralogy and Petrology, v. 98, p. 1-17, doi:10.1007/s00710-009-0064-3.

Rooney, T.O., 2010, Geochemical evidence of lithospheric thinning in the southern Main Ethiopian Rift: Lithos, v. 117, p. 33-48, doi:10.1016/j .lithos.2010.02.002.

Rooney, T.O., Furman, T., Yirgu, G., and Ayalew, D., 2005, Structure of the Ethiopian lithosphere: Xenolith evidence in the Main Ethiopian Rift: Geochimica et Cosmochimica Acta, v. 69, no. 15, p. 3889-3910, doi:10.1016/j .gca.2005.03.043.

Rooney, T.O., Furman, T., Bastow, I.D., Ayalew, D., and Yirgu, G., 2007, Lithospheric modification during crustal extension in the Main Ethiopian Rift: Journal of Geophysical Research, v. 112, B10201, doi:10.1029/2006JB004916.

Rowland, J.V., Baker, E., Ebinger, C.J., Keir, D., Kidane, T., Biggs, J., Hayward, N., and Wright, T.J., 2007, Fault growth at a nascent slow-spreading ridge: 2005 Dabbahu rifting episode, Afar: Geophysical Journal International, v. 171, no. 3, p. 1226-1246, doi:10.1111/j.1365-246X.2007.03584.x.

Ruegg, J.C., and Kasser, M., 1987, Deformation across the Asal-Ghoubbet Rift, Djibouti, uplift and crustal extension 1979-1986: Geophysical Research Letters, v. 14, p. 745-748, doi:10.1029/GL014i007p00745.

Sicilia, D., Montagner, J.P., Cara, M., Stutzmann, E., Debayle, E., Lépine, J.C., Lévêque, J.J., Beucler, E., Sebai, A., Roult, G., Ayele, A., and Sholan, J.M., 2008, Upper mantle structure of shear-waves velocities and stratification of anisotropy in the Afar hotspot region: Tectonophysics, v. 462, no. 1-4, p. 164-177, doi:10.1016/j.tecto.2008.02.016.

Simmons, N.A., Forte, A.M., and Grand, S.P., 2007, Thermochemical structure and dynamics of the African superplume: Geophysical Research Letters, v. 34, no. 2, doi:10.1029/2006GL028009.

Sleep, N.H., 1996, Lateral flow of hot plume material ponded at sub-lithospheric depths: Journal of Geophysical Research, v. 101, p. 28,065-28,083, doi: 10.1029/96JB02463.

Soliva, R., and Schultz, R., 2008, Distributed and localized faulting in extensional settings: Insight from the north Ethiopian Rift-Afar transition area: Tectonics, v. 27, no. 2, TC2003, doi:10.1029/2007TC002148.

Stamps, D., Calais, E., Saria, E., Hartnady, C., Nocquet, J., Ebinger, C., and Fernandes, R., 2008, A kinematic model for the East African Rift: Geophysical Research Letters, v. 35, no. 5, L05304, doi:10.1029/2007GL032781.

Stein, R.S., Briole, P., Ruegg, J.C., Tapponnier, P., and Gasse, F., 1991, Contemporary Holocene, and Quaternary deformation of the Asal Rift, DjiboutiImplications for the mechanisms of slow spreading ridges: Journal of Geophysical Research, v. 96, p. 21,789-21,806, doi:10.1029/91JB02118.

Stuart, G., Bastow, I., and Ebinger, C., 2006, Crustal structure of the northern Main Ethiopian Rift from receiver function studies, in Yirgu, G., Ebinger, C.J., and Maguire, P.K.H., eds., The Afar Volcanic Province within the East African Rift System: Geological Society of London Special Publication 259, p. 253-267.

Tadesse, S., Milesi, J.-P., and Deschamps, Y., 2003, Geology and mineral potential of Ethiopia: A note on geology and mineral map of Ethiopia: Journal of African Earth Sciences, v. 36, p. 273-313, doi:10.1016/S0899 -5362(03)00048-4.

Tesfaye, S., Harding, D., and Kusky, T., 2003, Early continental breakup boundary and migration of the Afar triple junction, Ethiopia: Geological Society of America Bulletin, v. 115, no. 9, p. 1053-1067, doi:10.1130/B25149.1.

Thybo, H., and Nielsen, C.A., 2009, Magma-compensated crustal thinning in continental rift zones: Nature, v. 457, no. 7231, p. 873-876, doi:10.1038/ nature 07688 .

Tiberi, C., Ebinger, C., Ballu, V., Stuart, G.W., and Oluma, B., 2005, Inverse models of gravity data from the Red Sea-Aden-East African Rifts triple junction zone: Geophysical Journal International, v. 163, no. 2, p. 775787, doi:10.1111/j.1365-246X.2005.02736.x. 
Vail, J.R., 1983, Pan-African crustal accretion in north-east Africa: Journal of African Earth Sciences, v. 1, p. 285-294, doi:10.1016/S0731-7247 (83)80013-5.

Vauchez, A., Tomassi, A., Barruol, G., and Maumus, J., 2000, Upper mantle deformation and seismic anisotropy in continental rifts: Physics and Chemistry of the Earth, v. 25, no. 2, p. 111-117, doi:10.1016/S1464 -1895(00)00019-3.

Wang, Y., Forsyth, D.W., and Savage, B., 2009, Convective upwelling in the mantle beneath the Gulf of California: Nature, v. 462, no. 7272, p. 499 501, doi:10.1038/nature08552.

Whaler, K., 2006, Magnetotelluric fieldwork adventures in Africa: Astronomy \& Geophysics, v. 47, no. 2, p. 28-37, doi:10.1111/j.1468-4004 .2006.47228.x.

Whaler, K., and Hautot, S., 2006, The electrical resistivity structure of the crust beneath the northern Ethiopian Rift, in Yirgu, G., Ebinger, C.J., and Maguire, P.K.H., eds., The Afar Volcanic Province within the East African Rift System: Geological Society of London Special Publication 259, p. 293-305.

White, R.S. and McKenzie, D.P., 1989, Magmatism at rift zones: the generation of volcanic continental margins and flood basalts: Journal of Geophysical Research, v. 94, 7685-7729.

White, R.S., Smith, L.K., Roberts, A.W., Christie, P.A.F., Kusznir, N.J., and The iSIMM Team, 2008, Lower-crustal intrusion on the North Atlantic continental margin: Nature, v. 452, no. 7186, p. 460-464, doi:10.1038/ nature 06687.

Williams, F., Williams, M., and Aumento, F., 2004, Tensional fissures and crustal extension rates in the northern part of the Main Ethiopian Rift:
Journal of African Earth Sciences, v. 38, no. 2, p. 183-198, doi:10.1016/j .jafrearsci.2003.10.007.

WoldeGabriel, G., 1988, Volcanotectonic History of the Central Sector of the Main Ethiopian Rift: A Geochronological, Geochemical and Petrological Approach [Ph.D. thesis]: Cleveland, Ohio, Case Western Reserve University, $410 \mathrm{p}$.

Wolfe, C.J., Solomon, S.C., Laske, G., Collins, J.A., Detrick, R.S., Orcutt, J.A., Bercovici, D., and Hauri, E.H., 2009, Mantle shear-wave velocity structure beneath the Hawaiian hot spot: Science, v. 326, no. 5958, p. 1388, doi:10.1126/science.1180165.

Wolfenden, E., Ebinger, C.J., Yirgu, G., Deino, A., and Ayalew, D., 2004, Evolution of the northern Main Ethiopian Rift: Birth of a triple junction: Earth and Planetary Science Letters, v. 224, p. 213-228, doi:10.1016/j .eps1.2004.04.022.

Wolfenden, E., Ebinger, C.J., Yirgu, G., Renne, P., and Kelley, S.P., 2005, Evolution of a volcanic rifted margin: Southern Red Sea, Ethiopia: Geological Society of America Bulletin, v. 117, no. 7-8, p. 846-864, doi:10.1130/ B25516.1.

Wright, T.J., Ebinger, C., Biggs, J., Ayele, A., Yirgu, G., Keir, D., and Stork, A., 2006, Magma-maintained rift segmentation at continental rupture in the 2005 Afar dyking episode: Nature, v. 442, no. 7100, p. 291-294, doi:10.1038/nature04978.

Zhu, L., and Kanamori, H., 2000, Moho depth variation in southern California from teleseismic receiver functions: Journal of Geophysical Research, v. 105, no. B2, p. 2969-2980, doi:10.1029/1999JB900322.

Manuscript Accepted by the Society 9 November 2010 